\title{
Molybdate Based Ceramic Negative-Electrode Materials for Solid Oxide Cells
}

\author{
Graves, Christopher R.; Reddy Sudireddy, Bhaskar; Mogensen, Mogens Bjerg
}

Published in:

E C S Transactions

Link to article, DOI:

10.1149/1.3495841

Publication date:

2010

Document Version

Publisher's PDF, also known as Version of record

Link back to DTU Orbit

Citation (APA):

Graves, C. R., Reddy Sudireddy, B., \& Mogensen, M. B. (2010). Molybdate Based Ceramic Negative-Electrode Materials for Solid Oxide Cells. E C S Transactions, 28(11), 173-192. https://doi.org/10.1149/1.3495841

\section{General rights}

Copyright and moral rights for the publications made accessible in the public portal are retained by the authors and/or other copyright owners and it is a condition of accessing publications that users recognise and abide by the legal requirements associated with these rights.

- Users may download and print one copy of any publication from the public portal for the purpose of private study or research.

- You may not further distribute the material or use it for any profit-making activity or commercial gain

- You may freely distribute the URL identifying the publication in the public portal 


\title{
Molybdate Based Ceramic Negative-electrode Materials for Solid Oxide Cells
}

\author{
Christopher Graves ${ }^{\mathrm{a}, \mathrm{b}}$, Bhaskar Reddy Sudireddy ${ }^{\mathrm{b}}$, Mogens Mogensen $^{\mathrm{b}}$ \\ ${ }^{a}$ Lenfest Center for Sustainable Energy, and Department of Earth and Environmental \\ Engineering, Columbia University, New York, New York 10027, USA \\ ${ }^{\mathrm{b}}$ Fuel Cells and Solid State Chemistry Division, Risø National Laboratory for \\ Sustainable Energy, The Technical University of Denmark, 4000 Roskilde, Denmark
}

Novel molybdate materials with varying Mo valence were synthesized as possible negative-electrode materials for solid oxide cells. The phase, stability, microstructure and electrical conductivity were characterized. The electrochemical activity for $\mathrm{H}_{2} \mathrm{O}$ and $\mathrm{CO}_{2}$ reduction and $\mathrm{H}_{2}$ and $\mathrm{CO}$ oxidation was studied using simplified geometry point-contact electrodes. Unique phenomena were observed for some of the materials - they decomposed into multiple phases and formed a nanostructured surface upon exposure to operating conditions (in certain reducing atmospheres). The new phases and surface features enhanced the electrocatalytic activity and electronic conductivity. The polarization resistances of the best molybdates were two orders of magnitude lower than that of donor-doped strontium titanates. Many of the molybdate materials were significantly activated by cathodic polarization, and they exhibited higher performance for cathodic (electrolysis) polarization than for anodic (fuel cell) polarization, which makes them especially interesting for use in electrolysis electrodes.

\section{Introduction}

Fuel cells and electrolysis cells with solid oxide electrolytes are promising technologies for electrochemical energy conversion and could become key components of a sustainable energy future. A single cell can be operated reversibly as a solid oxide fuel cell (SOFC) and as a solid oxide electrolysis cell (SOEC), converting fuel to electricity and vice versa, respectively, and the high temperature operation enables high energy efficiency and high reaction rates. The microstructure of the conventional Ni-YSZ ceramic-metal negative-electrode of solid oxide cells has been optimized over the last several decades to provide high performance for fuel cell and electrolysis operation (YSZ = yttria-stabilized zirconia). However, the Ni-YSZ electrode is susceptible to poisoning by sulfur and other impurities that segregate to the three-phase boundary (TPB) [1] , and can be severely damaged by reduction-oxidation (redox) cycles due to the Ni-NiO phase transitions because the $\mathrm{Ni}$ is structural in these electrodes [2].

It is also possible to produce electrodes composed entirely of ceramic oxides. The typical positive-electrode (oxygen electrode) composed of lanthanum strontium manganite (LSM) and YSZ is such an electrode. Other commonly studied positiveelectrodes are ferrites and cobaltites. Because the negative-electrode has more stringent requirements, it has been more difficult to obtain a good ceramic negative-electrode. The more stringent requirements include stability at extremely low oxygen partial pressure and preferably redox stability (the positive-electrode need only be stable in air or pure oxygen type atmospheres so the materials are never reduced and need not be, and are not, redox stable). All-ceramic negative-electrodes have been actively studied since about 
1990 [3]. Several recent review articles have provided excellent overviews of the current state-of-the-art of ceramic negative-electrode material development [4-6]. Ceramics offer a number of possible advantages over metals, depending on the composition and preparation methods:

- Mixed ionic-electronic conductivity (MIEC) - This leads to a reactive surface with the reaction zone not only at the TPB. This can enhance the electrochemical performance, leading to lower polarization resistance. A mixed conductor is also likely more tolerant to impurities that collect at the TPBs, improving durability.

- Fine microstructures - Whereas metal particles agglomerate and creep, ceramic oxides do not (however they do still sinter, leading to increased grain size). Fine microstructures lead to a higher surface area and number of reaction sites, lowering the area-specific and material-quantity-specific polarization resistance.

- Redox stability - This improves the durability.

- Composed mostly of oxygen and alkaline/rare earths-More expensive transition metals typically make up 20 at $\%$ or less of the crystal lattice (typically $<33 \mathrm{wt} \%$ ), potentially improving the manufacturing cost.

Developing a high performance ceramic electrode could therefore improve the economics of solid oxide cells. Most of the ceramic materials that have been found to offer some of these properties have the fluorite or perovskite crystal structures. Fluorites offer mixed conductivity, but the electronic conductivity is not sufficient for current collection. Fluorites like doped ceria and YSZ exhibit sufficient oxide ion conductivity for use as electrolyte materials. Doped ceria is also useful as a surface catalyst [7,8]. Perovskites can offer very high electronic conductivity, and some compositions also show good ionic conductivity [9]. For both fluorites and perovskites, mixed conductivity is the result of defects in the crystal lattice.

The purpose of this work was to study fundamental properties of a number of molybdate based ceramic materials which might be useful as components of negativeelectrodes in solid oxide cells. The electrical conductivity, phase (and phase stability in different atmospheres) and microstructure of the materials were investigated. The electrochemical activity for electrolysis of $\mathrm{H}_{2} \mathrm{O}$ and $\mathrm{CO}_{2}$ and oxidation of $\mathrm{H}_{2}$ and $\mathrm{CO}$ was tested for some of the materials. The molybdate family is relatively unexplored for solid oxide cell applications. A few of the materials have been studied as fuel cell anodes in prior work and others are new materials from related families that have not been tested as solid oxide cell electrodes. None of the materials, including those that have been studied as fuel cell anodes, have been tested for electrolysis. Furthermore, the prior anode studies used porous electrodes, and most of them only reported the performance of the full cell (not isolating the performance of the electrode). In the present study, simplified geometry cone-shaped electrodes were employed. The electrodes contact YSZ with a well-defined three-phase boundary, enabling study of the electrochemical properties and relative electrocatalytic performance of the materials without the effects of a complex microstructure of porous electrodes. The simplified geometry also enables rapidly testing many electrodes composed of different materials without going through the entire microstructure development and optimization process needed to obtain useful results for a porous three-dimensional electrode.

In the following introductory sections, the prior studies of molybdate materials in solid oxide cells are reviewed, followed by a discussion about designing a molybdenumbased ceramic electrode. 
$\underline{\text { Prior Work with Molybdenum Based Ceramics in Solid Oxide Cells }}$

The first major material based on Mo that was studied for use in SOFCs was the oxide ion conductor, $\mathrm{La}_{2} \mathrm{Mo}_{2} \mathrm{O}_{9}[10]$. This material was found to have higher $\mathrm{O}^{2-}$ ion conductivity than YSZ at temperatures above $600{ }^{\circ} \mathrm{C}$, suggesting that it could be a good electrolyte material. However, it is unstable in reducing atmospheres in this temperature range, limiting its practical applicability.

The pyrochlore $\mathrm{Gd}_{2} \mathrm{Ti}_{\mathrm{y}} \mathrm{Mo}_{1-\mathrm{y}} \mathrm{O}_{7}$ was considered as a potential SOFC anode material due to its high electronic conductivity in reducing atmospheres as well as its ionic conductivity, making it a mixed conductor [11]. The oxidation performance was notable, with an area-specific polarization resistance $\left(\mathrm{ASR}_{\mathrm{P}}\right)$ of $0.2 \Omega \mathrm{cm}^{2}$ at $950{ }^{\circ} \mathrm{C}$ at open circuit voltage (OCV). This material exhibited high sulfur tolerance. In fact, remarkably, this anode had almost as high performance in $\mathrm{H}_{2} \mathrm{~S}$ as in $\mathrm{H}_{2}$.

Recently, the double perovskite $\mathrm{Sr}_{2} \mathrm{MgMoO}_{6}(\mathrm{SMM})$ was reported as an excellent $\mathrm{SOFC}$ anode material $[12,13]$. In fact, a variant with some La substituted for $\mathrm{Sr}$ is the highest performing single-phase anode material reported for $\mathrm{H}_{2}$ and $\mathrm{CH}_{4}$ oxidation to date [14]. Replacing Mn with Mg was also tested but had slightly lower performance $[12,13]$. With a lanthanum-doped ceria (LDC) layer between the SMM anode and a electrolyte to prevent undesirable reaction and interdiffusion, an $\mathrm{ASR}_{P}$ of $0.1-0.15 \Omega \mathrm{cm}^{2}$ (for 0 to 0.5 $1 \mathrm{~A} / \mathrm{cm}^{2}$ on a polarization curve) was reported at $800{ }^{\circ} \mathrm{C}$ in $\mathrm{H}_{2}$. Up to at least $50 \mathrm{ppm}$ $\mathrm{H}_{2} \mathrm{~S}$ tolerance, with minimal impact on performance, was reported $[12,13]$. An anode made of SMM is also believed to be redox-stable (although that is not the case with the La-substituted variant). The electrochemical activity is believed to be related to the mixed ionic-electronic conductivity of the material. The conductivity of $4-9 \mathrm{~S} / \mathrm{cm}$ in reducing atmospheres is sufficient, although there have been a wider range of conductivity values reported since the initial study $[12,15-17]$. This material and some related double perovskites are studied further in the present work. Some studies of the related double perovskites were reported while the present work was carried out, and will be discussed and compared to the results obtained here in the Results sections. The results are able to explain some of the inconsistencies in the properties reported for these double perovskites in the recent literature.

Finally, an amorphous lanthanum molybdate (LaMoO) was recently reported as a high performance SOFC anode material. This material was in fact prepared by reducing the oxide-ion conductor mentioned above, $\mathrm{La}_{2} \mathrm{Mo}_{2} \mathrm{O}_{9}$, which decomposed it to an amorphous phase. For a full cell with an LDC buffer layer, similar performance was reported [18] as the full cell performance reported for SMM [12, 13]. 20 ppm sulfur tolerance was also reported. This material is also included in the present study.

\section{Designing a Molybdenum-based Electrode}

The elements molybdenum and tungsten have interesting properties. While Mo based ceramics are the focus of this study, tungsten is included based on its similarity to Mo. They are the only elements that prefer the +6 valence state at normal oxidized conditions. $\mathrm{MoO}_{3}$ and $\mathrm{WO}_{3}$ are perovskites with all vacancies for the A-sites. They have a large valence range of 0 to 6 , rivaled only by $\mathrm{Mn}$ and the more expensive elements $\mathrm{Ru}$, $\mathrm{Os}$, Rh, and Ir. The tungsten bronze $(\mathrm{Na} / \mathrm{K})_{\mathrm{x}} \mathrm{WO}_{3}$ and the perovskite $\mathrm{SrMoO}_{3}$ have applications in electrochromics [19,20], very high conductivity oxides [21-24], and catalysis [25-27]. Ni-Mo and Ni-W alloy electrodes with fine micro- or nano-structures 
have been reported as highly electrocatalytic negative-electrodes for alkaline electrolysis cells, improving upon the performance of Ni electrodes [28-30].

In the perovskite $\mathrm{SrMoO}_{3}$, the Mo valence is 4+. One may consider the ionic radii and the Goldschmidt tolerance factor $t=\left(r_{A}+r_{O}\right) /\left(\sqrt{2} \cdot\left(r_{B}+r_{O}\right)\right)$ where $\mathrm{r}_{\mathrm{A}}, \mathrm{r}_{\mathrm{B}}$, and $\mathrm{r}_{\mathrm{O}}$ are the ionic radii of the $\mathrm{A}-\mathrm{B}, \mathrm{B}-$, and $\mathrm{O}$-site ions of an $\mathrm{ABO}_{3}$ perovskite, respectively. The ionic radii for the ions relevant to the present study are shown in Table 1. If the dimensionless value of the tolerance factor $t$ is close to 1 , the ions are the ideal size for fitting into their cavities in the perovskite structure and the structure is expected to adopt the ideal cubic symmetry. Note that the tolerance factor is very close to 1 for $\mathrm{SrMoO}_{3}\left(\mathrm{Mo}^{4+}\right)$ as well as for $\mathrm{SrTiO}_{3}\left(\mathrm{Ti}^{4+}\right)-0.98$ and 1.00 respectively.

In Mo-based double perovskites, Mo is also on the $\mathrm{B}$ site, but $\mathrm{Mo}^{6+}$ or $\mathrm{Mo}^{5+}$ is paired with a $2+$ or $3+$ valence ion respectively. The differences in charge and ionic radii result in $6+/ 2+$ or $5+/ 3+$ ordering and a superlattice structure (see Table 1 for the relevant ionic radii). Of the $2+$ ions, $\mathrm{Mg}$ is the most stable against reduction, according to thermodynamics [31]. The mechanism for high electrochemical performance proposed by Huang et al for the double perovskite anode $\mathrm{Sr}_{2} \mathrm{MgMoO}_{6}$ is mixed conductivity [12, 13]. When the material is reduced, oxygen is lost from the crystal structure, resulting in the formation of oxygen vacancies and electrons. A fraction of the $\mathrm{Mo}^{6+}$ ions accept the electrons and become $\mathrm{Mo}^{5+}$. Both the $6+$ and $2+$ ions in the double perovskite must have coordination flexibility to allow release of oxygen from the crystal lattice [13]. The electromagnetic properties of double perovskites vary significantly depending on the partner 2+/3+ ion [32-34].

Table 1. Ionic radii $(\AA)$ for VI-fold coordination [36]. ls = low spin; hs = high spin.

\begin{tabular}{|c|c|c|c|c|c|c|c|c|c|c|}
\hline Valence & Mo & $\mathrm{W}$ & $\mathrm{Ti}$ & $\mathrm{Nb}$ & Valence & $\mathrm{Mg}$ & $\mathrm{Mn}$ & $\mathrm{Ni}$ & $\mathrm{Fe}$ & $\mathrm{Co}$ \\
\hline+4 & 0.65 & 0.66 & 0.605 & 0.68 & +2 & 0.72 & $0.67(1 \mathrm{~s})$ & 0.69 & $0.61(\mathrm{ls})$ & $0.65(\mathrm{ls})$ \\
\hline+5 & 0.61 & 0.62 & & 0.64 & & & $0.83(\mathrm{hs})$ & & $0.78(\mathrm{hs})$ & $0.745(\mathrm{hs})$ \\
\hline+6 & 0.59 & 0.60 & & & +3 & & $0.58(\mathrm{ls})$ & $0.56(1 \mathrm{~s})$ & $0.55(1 \mathrm{~s})$ & 0.545 (ls) \\
\hline & & & & & & & $0.645(\mathrm{hs})$ & $0.60(\mathrm{hs})$ & $0.645(\mathrm{hs})$ & $0.61(\mathrm{hs})$ \\
\hline
\end{tabular}

One must also consider the thermodynamic stability of the valence states of the ions during synthesis and operation. Diagrams of phase stability versus temperature and $p \mathrm{O}_{2}$ for the Mo-O and $\mathrm{W}-\mathrm{O}$ systems are shown in Figure 1. These are the constituent oxides of the materials, e.g. $\mathrm{SrO}+\mathrm{MoO}_{2} \rightarrow \mathrm{SrMoO}_{3}$. Knowledge of the preferred valence state based on the constituent oxides is useful as a guideline for synthesis parameters and as an indication of possible stability ranges during operation. Also marked on the diagram are typical operating conditions, $700-900{ }^{\circ} \mathrm{C}$ and $3 \%, 50 \%$, and $90 \% \mathrm{H}_{2} \mathrm{O} / \mathrm{H}_{2}$. The $3 \%$ and $90 \% \mathrm{H}_{2} \mathrm{O}$ conditions represent SOFC and SOEC inlet conditions, and the $50 \% \mathrm{H}_{2} \mathrm{O}$ condition represents the average gas compositions that would be seen across an operating cell (in either mode, fuel cell or electrolysis) run at high reactant utilization. 


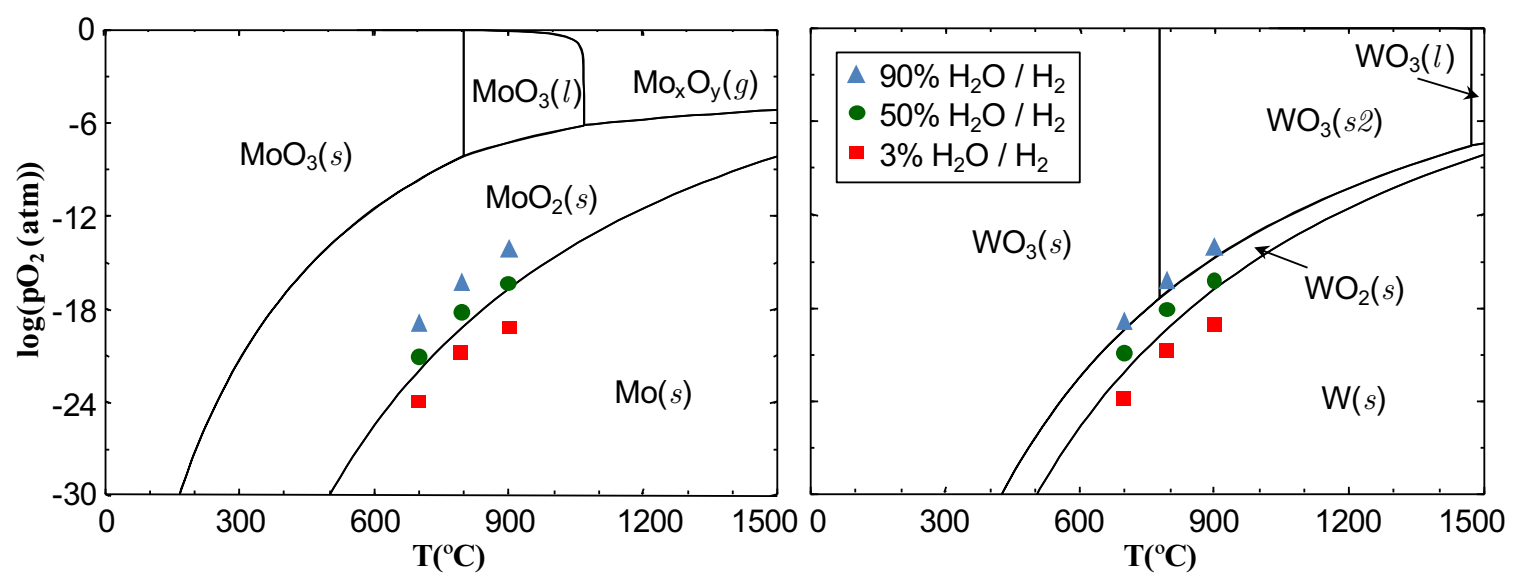

Figure 1. Phase stability for the Mo-O and W-O systems, according to thermodynamic data [31].

\section{Experimental}

Sample Preparation

A variety of molybdate-based materials were studied. The composition of the materials was systematically varied within the molybdate family, with $12.5-100$ at $\%$ Mo on the $\mathrm{B}$ site of the $\mathrm{ABO}_{3}$ perovskites. Two materials with Mo completely replaced with $\mathrm{W}$ were also included. Other elements, based on their ionic radii and properties of potential stability and electrochemical activity, were introduced alongside Mo on the Bsite. The compositions prepared are $\mathrm{SrMoO}_{3}$, amorphous $\mathrm{LaMoO}, \mathrm{Sr}_{2} \mathrm{CoMoO}_{6}$, $\mathrm{Sr}_{2} \mathrm{FeMoO}_{6}, \quad \mathrm{Sr}_{2} \mathrm{MgMoO}_{6}, \quad \mathrm{Sr}_{2} \mathrm{MgWO}_{6}, \quad \mathrm{Sr}_{2} \mathrm{NiMoO}_{6}, \quad \mathrm{Sr}_{2} \mathrm{NiWO}_{6}, \quad \mathrm{SrTi}_{0.5} \mathrm{Mo}_{0.5} \mathrm{O}_{3}$, $\mathrm{SrTi}_{0.5} \mathrm{Ni}_{0.25} \mathrm{Mo}_{0.25} \mathrm{O}_{3}$, and $\mathrm{SrV}_{0.5} \mathrm{Mo}_{0.5} \mathrm{O}_{3}$. The compositions, B-site valences, crystal structures, and tolerance factors are given in Table 2. Polycrystalline samples were synthesized by solid state reaction (e.g. for $\mathrm{Sr}_{2} \mathrm{MgMoO}_{6}: 2 \mathrm{SrCO}_{3}+\mathrm{MgO}+\mathrm{MoO}_{3} \rightarrow$ $\mathrm{Sr}_{2} \mathrm{MgMoO}_{6}+\mathrm{CO}_{2}$ ). Oxide and carbonate powders were mixed in stoichiometric quantities with ethanol and roll milled with YSZ balls for 12-24 h. The purities of the precursor powders were $>99.5 \%$ except for $\mathrm{NiO}$ which was $99 \%$. The slurry was dried, hand-ground, and the powder was heat treated to form the desired phase. Some heat treatments were in air and others were in $9 \% \mathrm{H}_{2} / \mathrm{Ar}$, room-temperature humidified $9 \%$ $\mathrm{H}_{2} / \mathrm{Ar}$ (adding $\sim 3 \% \mathrm{H}_{2} \mathrm{O}$ ), or humidified 9\% $\mathrm{H}_{2} / \mathrm{Ar}$ through a bubbler that was refrigerated (adding about $1.3 \% \mathrm{H}_{2} \mathrm{O}$ ) depending on the composition. The heat treated powders were pressed into bars and pellets to prepare for sintering dense bodies. They were uniaxially pressed at 50-100 $\mathrm{MPa}$ and then isostatically pressed at $250 \mathrm{MPa}$. The green bodies were sintered in air or humidified $9 \% \mathrm{H}_{2} / \mathrm{Ar}$ depending on the composition. After each heat treatment and sintering, the phase of the powders or sintered bodies was examined by x-ray diffraction (XRD) using a STOE Diffractometer with $\mathrm{Cu}-\mathrm{K} \alpha$ radiation. After sintering, some samples of each material were polished and examined in the SEM/EDX (a Zeiss Supra 35 FE-SEM equipped with a Noran System SIX X-ray microanalysis system). The heat treatment conditions for successful phase formation and sintering for each material are reported and discussed in the Results section below. 
Table 2. The molybdate materials that were synthesized and studied in the present work. The tolerance factors were calculated using the low-spin ionic radii.

\begin{tabular}{|c|c|c|c|c|c|}
\hline Composition & \multicolumn{2}{|c|}{ B site composition } & Acronym & Crystal structure & Tol. factor \\
\hline $\mathrm{SrMoO}_{3}$ & \multicolumn{2}{|c|}{$\mathrm{Mo}^{4+}$} & SM & Perovskite & 0.98 \\
\hline LaMoO & \multicolumn{2}{|c|}{$\mathrm{Mo}^{\text {varioust }}$} & LM & Amorphous & - \\
\hline $\mathrm{Sr}_{2} \mathrm{CoMoO}_{6}$ & $\mathrm{Mo}^{6+}$ & $\mathrm{Co}^{2+}$ & SCM & Double perovskite & 0.99 \\
\hline $\mathrm{Sr}_{2} \mathrm{FeMoO}_{6}$ & $\mathrm{Mo}^{5+/ 6+}$ & $\mathrm{Fe}^{2+/ 3+}$ & SFM & Double perovskite & $1.00^{\mathrm{a}}$ \\
\hline $\mathrm{Sr}_{2} \mathrm{MgMoO}_{6}$ & $\mathrm{Mo}^{6+}$ & $\mathrm{Mg}^{2+}$ & SMM_1 & Double perovskite & 0.98 \\
\hline $\mathrm{Sr}_{2} \mathrm{MgMoO}_{6-\delta}{ }^{\mathrm{b}}$ & $\mathrm{Mo}^{5+/ 6+}$ & $\mathrm{Mg}^{2+}$ & SMM_2 & Double perovskite & 0.98 \\
\hline $\mathrm{Sr}_{2} \mathrm{MgWO}_{6}$ & $\mathrm{~W}^{6+}$ & $\mathrm{Mg}^{2+}$ & SMW & Double perovskite & 0.97 \\
\hline $\mathrm{Sr}_{2} \mathrm{NiMoO}_{6}$ & $\mathrm{Mo}^{6+}$ & $\mathrm{Ni}^{2+}$ & SNM & Double perovskite & 0.98 \\
\hline $\mathrm{Sr}_{2} \mathrm{NiWO}_{6}$ & $\mathrm{~W}^{6+}$ & $\mathrm{Ni}^{2+}$ & SNW & Double perovskite & 0.98 \\
\hline $\mathrm{SrTi}_{0.5} \mathrm{Mo}_{0.5} \mathrm{O}_{3}$ & $\mathrm{Mo}^{4+}$ & $\mathrm{Ti}^{4+}$ & STM & Perovskite & 0.99 \\
\hline $\mathrm{SrTi}_{0.5} \mathrm{Ni}_{0.25} \mathrm{Mo}_{0.25} \mathrm{O}_{3}$ & $\mathrm{Mo}^{6+} \mathrm{Ni}^{2+}$ & $\mathrm{Ti}^{4+}$ & STNM502525 & (Double?) perovskite & 0.99 \\
\hline $\mathrm{SrV}_{0.5} \mathrm{Mo}_{0.5} \mathrm{O}_{3}$ & $\mathrm{Mo}^{4+}$ & $\mathrm{V}^{4+}$ & SVM & Perovskite & 1.00 \\
\hline
\end{tabular}

a Tolerance factor for $\mathrm{Fe}^{2+}$ and $\mathrm{Mo}^{6+}$ or $\mathrm{Mo}^{5+}$. The exact amounts of $\mathrm{Fe}^{2+}, \mathrm{Fe}^{3+}, \mathrm{Mo}^{5+}$, and $\mathrm{Mo}^{6+}$ are not known. For $\mathrm{Fe}^{3+}$ and $\mathrm{Mo}^{5+}$, the tolerance factor is slightly higher, 1.01 .

${ }^{\mathrm{b}}$ Synthesized in reducing atmosphere (see Table 3 ).

\section{Conductivity}

Conventional 4-point DC conductivity tests were performed on the sintered bars. First, \#320 SiC grinding paper was used to remove a few microns from all surfaces of the bars. Pt wire and Pt paste were used to form the current leads at each end of a bar. Pt wire voltage probes with a fixed separation distance (built into the test set-up) were contacted to the surface.

\section{Electrochemistry}

Electrochemistry tests were performed on most of the materials using pointcontact electrodes. The cells consisted of pointed ceramic electrodes contacting a smooth polished YSZ pellet surface, with a much larger porous Pt counter electrode acting as a reference electrode (pseudo 3-electrode setup, see Figure 2), similar to the metal point electrode tests described in ref. [37]. The pointed electrodes were prepared from the sintered pellets by grinding the pellets to a cone-like shape, as has been used in prior work [38-45]. In the present study, however, the pointed electrodes were made by handgrinding on SiC paper affixed to a grinding wheel, with the grinding direction away from the tip so as to avoid getting $\mathrm{SiC}$ particles lodged in the electrode, which would contaminate the electrode with impurities. This most often resulted in more of a "pyramid" shape rather than cone shape. It was found that equivalent results could be obtained by machining the pellets into a cone versus the hand-grinding method. In fact, a number of electrode geometries using the same material were tested, as it was desired to find a standard platform to quickly test the electrochemical properties of different materials without going through the entire cell development process. The advantages and disadvantages of the different geometries will be reported in the future. The pointcontact geometry is a very useful, especially if the TPB can be measured after testing and used to apply correction factors to the Newman relation as done for the metal point electrode study of ref. [37]. However, using such point-contact electrodes is generally less straightforward for ceramics than for metals because the ceramics are not soft like metals and do not creep and form a well-defined interface and TPB. In the present study, methods were developed to successfully measure the TPB for ceramic materials, 
improving upon prior point-contact ceramic electrodes studies. For the molybdate materials, preparation conditions were found for which it was possible to observe the TPB in the SEM after testing and measure its length.
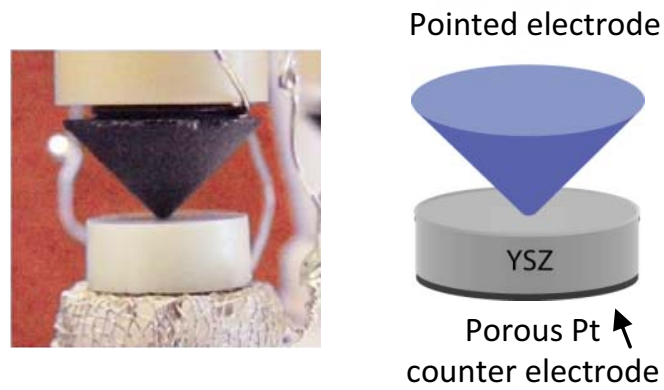

Figure 2. Photograph and diagram of a ceramic cone-type point electrode used in the electrochemistry tests.

After assembling the cells, they were heated up to $850{ }^{\circ} \mathrm{C}$ in dry $9 \% \mathrm{H}_{2} / \mathrm{Ar}$ (or $9 \%$ $\mathrm{H}_{2} / \mathrm{Ar}$ that was humidified with $1 \% \mathrm{H}_{2} \mathrm{O}$ for some of the samples). The gas atmosphere was switched to $3 \% \mathrm{H}_{2} \mathrm{O} / \mathrm{H}_{2}$ and impedance spectra (IS) were measured constantly at OCV while the interface stabilized, usually $12-24 \mathrm{~h}$ but in some cases up to $100 \mathrm{~h}$ to allow time to reduce the ceramic electrode material if it was not pre-reduced. The potentiostatic IS measurements typically used 6 to 9 points per decade, from $1 \mathrm{MHz}$ to 3 $\mathrm{mHz}$, with an AC RMS amplitude of $10 \mathrm{mV}$, using a Gamry Reference 600. OCV IS were measured at different temperatures from 850 to $700{ }^{\circ} \mathrm{C}$, repeating a set-point more than once to check if the electrode performance had changed during the temperature variation. The gas atmosphere was changed to $50 \% \mathrm{H}_{2} \mathrm{O} / \mathrm{H}_{2}$ and to $50 \% \mathrm{CO}_{2} / \mathrm{CO}$ and the temperature variation was repeated for each. In $50 \% \mathrm{H}_{2} \mathrm{O} / \mathrm{H}_{2}$ and $50 \% \mathrm{CO}_{2} / \mathrm{CO}$, cyclic potential sweeps were performed from OCV to $+300 \mathrm{mV}$ to $-300 \mathrm{mV}$ to OCV for at least 3 cycles. Finally, IS were measured under polarization in $100 \mathrm{mV}$ increments, in the order OCV, $+100 \mathrm{mV},+200 \mathrm{mV},+300 \mathrm{mV},-100 \mathrm{mV},-200 \mathrm{mV},-300 \mathrm{mV}$, with 5 minutes of fixed DC bias (chronoamperometry) at each given applied potential before the IS measurement. 2 or 3 electrodes of the same material were tested for 4 of the materials (SFM, SMM, SNM, and STM50), and 1 electrode was tested for the remaining materials.

\section{Results and Discussion}

\section{Materials Synthesis}

The optimized synthesis parameters are given for each material in Table 3 . In some cases, Heating \#1 was an initial heat treatment in air which was used to decompose the $\mathrm{SrCO}_{3} \quad$ For other materials Heating \#1 was used to form an intermediate phase: for SM synthesis, the first heat treatment was $1000{ }^{\circ} \mathrm{C}$ for $8 \mathrm{~h}$ in air to form the oxidized phase, $\mathrm{SrMoO}_{4}$. The $\mathrm{SrMoO}_{4}$ was subsequently reduced in the listed Heating \#2. According to literature [24, 27, 46-49] and trials conducted in the present study, this is the most reliable way to obtain $\mathrm{SrMoO}_{3}$. Similarly, for $\mathrm{LaMoO}$ an initial heat treatment of $950{ }^{\circ} \mathrm{C}$ for $10 \mathrm{~h}$ in air was used to obtain $\mathrm{La}_{2} \mathrm{Mo}_{2} \mathrm{O}_{9}$. As in ref. [18], the $\mathrm{La}_{2} \mathrm{Mo}_{2} \mathrm{O}_{9}$ was subsequently reduced to decompose it to an amorphous phase. The sintered densities were $>90 \%$ theoretical density for $1400{ }^{\circ} \mathrm{C}$ sintered samples and $>66 \%$ for the $1300{ }^{\circ} \mathrm{C}$ sintered samples. 
Successful synthesis of the desired phase was often $p \mathrm{O}_{2}$ dependent - to obtain a reduced Mo valence, a reducing atmosphere was needed. Over-reduction can yield Mo metal however, so careful control of the $p \mathrm{O}_{2}$ is necessary. Of the double perovskites, all that have $2+/ 6+$ ordering when oxidized were possible to synthesize in air. In the literature, SMM produced by sol-gel synthesis is often sintered in reducing atmosphere [12], so a different sample, SMM_2, was sintered in reducing atmosphere - this will be further discussed in the following section. SFM had a narrower window of suitable $p \mathrm{O}_{2}$ required to form the phase and could not be synthesized in air - one or both of $\mathrm{Fe}^{2+/ 3+}$ and $\mathrm{Mo}^{6+}$ needed to be reduced. Synthesis in air yielded segregation of $\mathrm{SrMoO}_{4}$, and overreduction yielded the Ruddleston-Popper phase $\mathrm{Sr}_{3} \mathrm{FeMoO}_{6.88}$ as has been reported in literature [50].

Table 3. Optimized synthesis parameters for the molybdate materials. " $\mathrm{H}$ " stands for dry $9 \% \mathrm{H}_{2} / \mathrm{Ar}$. "w" stands for "wet" (room-temperature humidified $\left.\sim 3 \% \mathrm{H}_{2} \mathrm{O}\right)$; "cw" stands for "cold-wet" $\left(\sim 1.3 \% \mathrm{H}_{2} \mathrm{O}\right)$.

\begin{tabular}{|c|c|c|c|c|c|c|c|c|c|c|c|c|}
\hline \multirow[b]{2}{*}{ Composition } & \multirow{2}{*}{\multicolumn{2}{|c|}{ B site composition }} & \multirow[b]{2}{*}{ Acronym } & \multicolumn{3}{|c|}{$\begin{array}{l}\text { Heating \#1 } \\
\text { (powder) }\end{array}$} & \multicolumn{3}{|c|}{$\begin{array}{l}\text { Heating \#2 (form } \\
\text { phase, powder) }\end{array}$} & \multicolumn{3}{|c|}{$\begin{array}{c}\text { Sinter dense } \\
\text { sample }\end{array}$} \\
\hline & & & & ${ }^{\circ} \mathrm{C}$ & $\mathrm{hr}$ & gas & ${ }^{\circ} \mathrm{C}$ & $\mathrm{hr}$ & gas & ${ }^{\circ} \mathrm{C}$ & $\mathrm{hr}$ & gas \\
\hline $\mathrm{SrMoO}_{3}$ & \multicolumn{2}{|c|}{$\mathrm{Mo}^{4+}$} & SM & 1000 & 8 & air & 800 & 26 & $\mathrm{H}$ & 1300 & 12 & $\mathrm{CW}-\mathrm{H}$ \\
\hline LaMoO & \multicolumn{2}{|c|}{ Movarioust } & LM & 950 & 10 & air & 900 & 10 & $\mathrm{H}$ & 1200 & 10 & $\mathrm{w}-\mathrm{H}$ \\
\hline $\mathrm{Sr}_{2} \mathrm{CoMoO}_{6}$ & $\mathrm{Mo}^{6+}$ & $\mathrm{Co}^{2+}$ & $\mathrm{SCM}$ & - & - & - & 1300 & 12 & air & 1400 & 12 & air \\
\hline $\mathrm{Sr}_{2} \mathrm{FeMoO}_{6}$ & $\mathrm{Mo}^{5+/ 6+}$ & $\mathrm{Fe}^{2+/ 3+}$ & SFM & 900 & 4 & air & 1250 & 12 & $\mathrm{w}-\mathrm{H}$ & 1400 & 12 & $\mathrm{w}-\mathrm{H}$ \\
\hline $\mathrm{Sr}_{2} \mathrm{MgMoO}_{6}$ & $\mathrm{Mo}^{6+}$ & $\mathrm{Mg}^{2+}$ & SMM_1 & - & - & - & 1300 & 12 & air & 1400 & 12 & air \\
\hline $\mathrm{Sr}_{2} \mathrm{MgMoO}_{6-\delta}$ & $\mathrm{Mo}^{5+/ 6+}$ & $\mathrm{Mg}^{2+}$ & SMM_2 & 850 & 12 & air & 1200 & 24 & $\mathrm{H}$ & 1350 & 18 & $\mathrm{w}-\mathrm{H}$ \\
\hline $\mathrm{Sr}_{2} \mathrm{MgWO}_{6}$ & $w^{6+}$ & $\mathrm{Mg}^{2+}$ & SMW & 900 & 12 & air & 1200 & 24 & $\mathrm{H}$ & 1350 & 18 & $\mathrm{w}-\mathrm{H}$ \\
\hline $\mathrm{Sr}_{2} \mathrm{NiMoO}_{6}$ & $\mathrm{Mo}^{6+}$ & $\mathrm{Ni}^{2+}$ & SNM & - & - & - & 1300 & 12 & air & 1400 & 12 & air \\
\hline $\mathrm{Sr}_{2} \mathrm{NiWO}_{6}$ & $\mathrm{~W}^{6+}$ & $\mathrm{Ni}^{2+}$ & SNW & - & - & - & 1300 & 12 & air & 1400 & 12 & air \\
\hline $\mathrm{SrTi}_{0.5} \mathrm{Mo}_{0.5} \mathrm{O}_{3}$ & $\mathrm{Mo}^{4+}$ & $\mathrm{Ti}^{4+}$ & STM & 1200 & 12 & $\mathrm{w}-\mathrm{H}$ & 1200 & 10 & $\mathrm{CW}-\mathrm{H}$ & 1440 & 12 & $\mathrm{CW}-\mathrm{H}$ \\
\hline $\mathrm{SrTi}_{0.5} \mathrm{Ni}_{0.25} \mathrm{Mo}_{0.25} \mathrm{O}_{3}$ & $\mathrm{Mo}^{6+} \mathrm{Ni}^{2+}$ & $\mathrm{Ti}^{4+}$ & STNM502525 & - & - & - & 1300 & 12 & air & 1400 & 12 & air \\
\hline $\mathrm{SrV}_{0.5} \mathrm{Mo}_{0.5} \mathrm{O}_{3}$ & $\mathrm{Mo}^{4+}$ & $\mathrm{V}^{4+}$ & SVM & - & - & - & 900 & 10 & $\mathrm{CW}-\mathrm{H}$ & 1300 & 12 & $\mathrm{CW}-\mathrm{H}$ \\
\hline
\end{tabular}

High phase purity was obtained for all materials except the reducing-sintered $\mathrm{SMM} 2$, in which impurity phases $\left(\mathrm{MgO}, \mathrm{SrMoO}_{4}\right.$, and $\left.\mathrm{Sr}_{3} \mathrm{MoO}_{6}\right)$ were present. These impurity phases were not present in the reducing-sintered SMM reported in literature [12], however in that study the powder was prepared by sol-gel synthesis and the sintering temperature was only $1200{ }^{\circ} \mathrm{C}$ and in a more strongly reducing atmosphere of dry $5 \%$ $\mathrm{H}_{2} /$ Ar. The powder in that study had a finer particle size and the intent was to sinter a porous electrode microstructure, not a dense sample. Here, on the other hand, solid state reaction was used and a dense sample was desired, so a higher sintering temperature was required. A stronger reducing atmosphere was found to result in the formation of Mo metal so the humidified $9 \% \mathrm{H}_{2} / \mathrm{Ar}$ atmosphere was used.

For the air-sintered samples, the compositions and synthesis conditions were optimized to eliminate $\mathrm{SrMoO}_{4}$ and $\mathrm{SrWO}_{4}$ impurities, which are commonly reported in literature to form during sintering in air (and found in the present study before optimization). Part of the optimization consisted of adding excess $\mathrm{NiO} / \mathrm{MgO} / \mathrm{etc}$ to obtain the single phase material. It was found afterwards that another group recently reported needing to add $5 \mathrm{wt} \%$ excess $\mathrm{NiO}$ when preparing $\mathrm{Sr}_{2} \mathrm{NiMoO}_{6}$ by solid state reaction [51]. It is also worth noting that any remaining $\mathrm{SrMoO}_{4}$ will reduce to $\mathrm{SrMoO}_{3}$ in operating conditions - as mentioned earlier, this is in fact how $\mathrm{SrMoO}_{3}$ was prepared in the present study, and the $\mathrm{SrMoO}_{3}+1 / 2 \mathrm{O}_{2} \leftrightarrow \mathrm{SrMoO}_{4}$ phase transition is reversible. $\mathrm{Sr}_{3} \mathrm{MoO}_{6}$ might also disappear during reduction. XRD data from a few of the compositions is shown in Figure 3. 

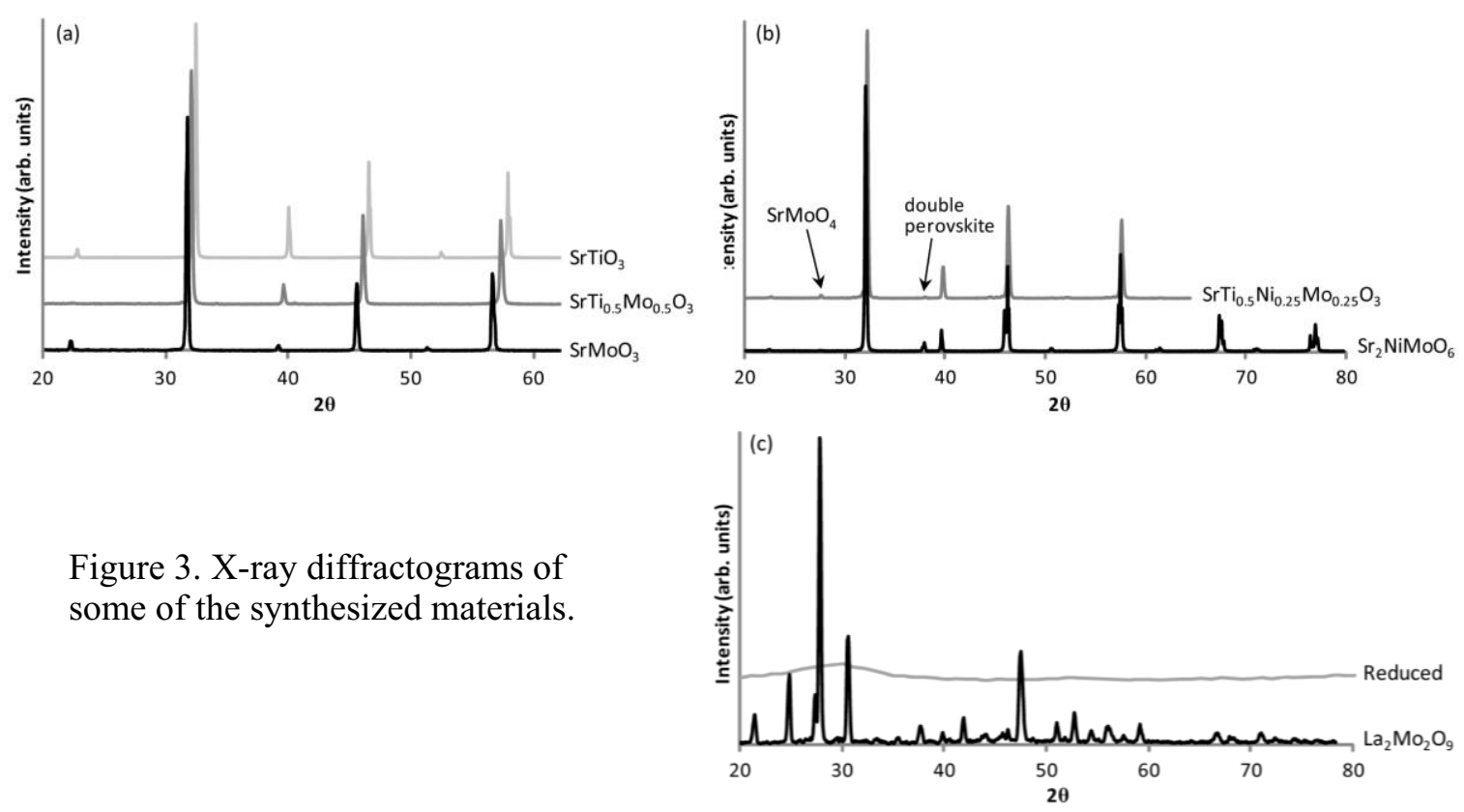

Figure 3. X-ray diffractograms of some of the synthesized materials.

$\mathrm{SrMoO}_{3}$ and $\mathrm{SrTiO}_{3}$ appear to form a solid solution in $\mathrm{SrTi}_{0.5} \mathrm{Mo}_{0.5} \mathrm{O}_{3}$ - the peaks measured for $\mathrm{SrTi}_{0.5} \mathrm{Mo}_{0.5} \mathrm{O}_{3}$ fell directly between those of $\mathrm{SrMoO}_{3}$ and $\mathrm{SrTiO}_{3}$ (Figure 3a). A solid solution was also found for $\mathrm{SrMo}_{0.5} \mathrm{~V}_{0.5} \mathrm{O}_{3}$. Based on the similar ionic radii, solid solutions are not unexpected and a literature search showed that they have been reported [52-54].

The double perovskites are all tetragonal at room temperature, evident by their peak splitting as shown for $\mathrm{Sr}_{2} \mathrm{NiMoO}_{6}$ (Figure 3b). They typically exhibit transition to cubic at 200-300 ${ }^{\circ} \mathrm{C}[16,51,55-60]$. The double-perovskite titanate hybrid, $\mathrm{SrTi}_{0.5} \mathrm{Ni}_{0.25} \mathrm{Mo}_{0.25} \mathrm{O}_{3}$, showed peaks between that of $\mathrm{Sr}_{2} \mathrm{NiMoO}_{6}$ and $\mathrm{SrTiO}_{3}$ (evident by the slight $2 \theta$ offset between $\mathrm{Sr}_{2} \mathrm{NiMoO}_{6}$ and $\mathrm{SrTi}_{0.5} \mathrm{Ni}_{0.25} \mathrm{Mo}_{0.25} \mathrm{O}_{3}$ ) - similar to $\mathrm{SrTi}_{0.5} \mathrm{Mo}_{0.5} \mathrm{O}_{3}$ in that both exhibited peaks in between their component oxides. Other XRD peaks that are indicative of double perovskites were present for $\mathrm{SrTi}_{0.5} \mathrm{Ni}_{0.25} \mathrm{Mo}_{0.25} \mathrm{O}_{3}$, but they were much smaller than those visible for $\mathrm{Sr}_{2} \mathrm{NiMoO}_{6}$. This could be the result of either some long-range ordering on the B-site, e.g. a pseudodouble perovskite with a new type of $\mathrm{Ni}^{2+} / \mathrm{Ti}^{4+} / \mathrm{Mo}^{6+}$ ordering, or the material might just be a composite of the two phases. Further crystallographic and microstructural studies are needed to determine if it is single-phase or a composite.

Finally, the XRD data showing the reduction of $\mathrm{La}_{2} \mathrm{Mo}_{2} \mathrm{O}_{9}$ to amorphous $\mathrm{LaMoO}$ is presented in Figure 3c and compares well with that presented in the prior work [18].

\section{Electrical Conductivity and Phase Stability}

The electrical conductivity was measured versus temperature and versus $p \mathrm{O}_{2}$. The measurements for the 100\% B-site Mo (SM and LM) and solid solutions (STM and SVM) are shown in Figure 4. SM clearly has extremely high conductivity (Figure 4a), near $10^{4} \mathrm{~S} / \mathrm{cm}$ at room temperature, which is consistent with literature [23, 24, 47, 61-63]. Its conductivity had not previously been reported for this high temperature range and $p \mathrm{O}_{2}$. At $800{ }^{\circ} \mathrm{C}$ the conductivity was just under $2000 \mathrm{~S} / \mathrm{cm}$ around $p \mathrm{O}_{2}=10^{-22}$ atm. However, when increasing the $p \mathrm{O}_{2}$ only slightly, to $10^{-20} \mathrm{~atm}$, the conductivity decreased to $<0.01$ 
$\mathrm{S} / \mathrm{cm}$. The material was oxidized and became the insulating $\mathrm{SrMoO}_{4}$ phase, at least on the surface where the voltage probes made contact. This is roughly consistent with the reported narrow $\mathrm{pO}_{2}$ window for stability of SM at the higher temperature of $1200{ }^{\circ} \mathrm{C}$ [46].

SVM (Figure 4b) and STM (Figure 4e) also exhibited very high conductivity, around $400 \mathrm{~S} / \mathrm{cm}$ at $800{ }^{\circ} \mathrm{C}$ in $10^{-20}$ atm $\mathrm{O}_{2}$. Similar values have been reported in literature for SVM $[53,54]$ and the similar $\mathrm{CaV}_{0.5} \mathrm{Mo}_{0.5} \mathrm{O}_{3}[54,64]$, as well as STM [52]. These materials are much more stable than SM at higher $p \mathrm{O}_{2}$, retaining high conductivity at a $p \mathrm{O}_{2}$ as high as $10^{-17}$ atm, which corresponds to $\mathrm{H}_{2} \mathrm{O}$-rich electrolysis type conditions with a $p \mathrm{H}_{2} \mathrm{O} / p \mathrm{H}_{2}$ ratio of 9 (Figure $4 \mathrm{c}$ and Figure 4f). It appears that conductivity was gained from $\mathrm{SrMoO}_{3}$ and stability was gained from $\mathrm{SrTiO}_{3}$ and $\mathrm{SrVO}_{3}$. Whereas $\mathrm{SrTiO}_{3}$ is an insulator, $\mathrm{SrVO}_{3}$ has been reported to have high metallic electronic conductivity [65, $66]$.

The amorphous lanthanum molybdate LM, on the other hand, exhibited low conductivity with semiconductor behavior - around $0.6 \mathrm{~S} / \mathrm{cm}$ at $800{ }^{\circ} \mathrm{C}$ in $10^{-20}$ atm $\mathrm{O}_{2}$ and slightly lower at $0.5 \mathrm{~S} / \mathrm{cm}$ with higher $p \mathrm{O}_{2}$ (Figure $4 \mathrm{~d}$ ). The $\log$ conductivity was linear with 1/T (not shown). The conductivity had not been reported in the LM anode study [18]. This low conductivity is only sufficient for a thin active layer of an electrode, not a current collecting layer [67, 68].

For the air-sintered double perovskite sample SMM_1, the conductivity at $800{ }^{\circ} \mathrm{C}$ in the very reducing dry $9 \% \mathrm{H}_{2} / \mathrm{Ar}$ atmosphere $\left(\mathrm{pO}_{2}=10^{-24} \overline{\mathrm{atm}}\right)$ was $3.5 \mathrm{~S} / \mathrm{cm}$ after more than 600 hours (not shown). On the other hand, the reducing-sintered sample SMM_2 did not need further reduction and reached a higher conductivity of $8.1 \mathrm{~S} / \mathrm{cm}$ at $800{ }^{\circ} \mathrm{C}$ in $10^{-20}$ atm $\mathrm{O}_{2}$ (Figure 5c). The conductivity increased to $12 \mathrm{~S} / \mathrm{cm}$ in $10^{-22.5} \mathrm{~atm} \mathrm{O}_{2}$ and decreased to $4 \mathrm{~S} / \mathrm{cm}$ in $10^{-17.5}$ atm $\mathrm{O}_{2}$, with an apparent linear log slope.

Clearly, the conductivity is a function of the $p \mathrm{O}_{2}$ during measurement and during sintering. The SMM 2 values are in agreement with those measured in the original study by Huang et al in which the material was sintered in a reducing atmosphere [12]. Thus it seems that the minor impurities phases present in the reducing-sintered sample in the present study were not detrimental to the conductivity. As mentioned earlier, many of these impurity phases will become reduced to more electron-conductive phases in situ. Also, impurity phases like $\mathrm{Sr}_{3} \mathrm{MoO}_{6}$ were found in a prior study of the related material SFM, present as islands that that did not affect the bulk material properties [69].

The widely varying conductivity values reported in literature for SMM can most likely be explained by the extent of reduction. The reported conductivity of air-sintered samples at $800{ }^{\circ} \mathrm{C}$ ranges from $0.3 \mathrm{~S} / \mathrm{cm}$ in $5 \% \mathrm{H}_{2} / \mathrm{Ar}$ [15], $1.6 \mathrm{~S} / \mathrm{cm}$ in $10^{-17}$ atm $\mathrm{O}_{2}$ [16], and $8.6 \mathrm{~S} / \mathrm{cm}$ in $5 \% \mathrm{H}_{2} / \mathrm{Ar}$ [17]. These are all lower than the value reached after $600 \mathrm{~h}$ in the present study, except for the $8.6 \mathrm{~S} / \mathrm{cm}$ measurement. However, that study reported that their sample had a significant amount of $\mathrm{SrMoO}_{4}$ impurity. As discussed above, $\mathrm{SrMoO}_{4}$ will reduce to $\mathrm{SrMoO}_{3}$ in reducing atmosphere, during the test, which could enhance the conductivity since $\mathrm{SrMoO}_{3}$ has such high conductivity. The reported conductivity of reducing-sintered samples ranges from $0.8 \mathrm{~S} / \mathrm{cm}$ in $5 \% \mathrm{H}_{2} / \mathrm{Ar}$ [15] to 8.6 $\mathrm{S} / \mathrm{cm}$ in $10^{-21} \mathrm{~atm} \mathrm{O}_{2}$ [12]. The latter is very close to the value obtained here in the similar $p \mathrm{O}_{2}$ of $10^{-20} \mathrm{~atm}$. The $0.8 \mathrm{~S} / \mathrm{cm}$ value may have been obtained on a sample that was sintered at a lower temperature or in a less reducing atmosphere. Alternatively, the $p \mathrm{O}_{2}$ during measurement was not specified and may be higher than expected. It is 
important that workers measure and report the $p \mathrm{O}_{2}$, because with dry " $5 \% \mathrm{H}_{2} / \mathrm{Ar}$ ", the $p \mathrm{O}_{2}$ depends largely on the seal-tightness of the set-up and how much $\mathrm{O}_{2}$ leaks in (plus any trace $\mathrm{O}_{2}$ in the feed gasses). There remains the question of the large difference between the equilibrium conductivity values of the air-sintered and reducing-sintered samples obtained in the present study $-3.5 \mathrm{~S} / \mathrm{cm}$ and $12 \mathrm{~S} / \mathrm{cm}$ at $10^{-24}$ and $10^{-23}$ atm $\mathrm{O}_{2}$ respectively. It seems very possible that the $3.5 \mathrm{~S} / \mathrm{cm}$ is the "true" conductivity for the material $\mathrm{Sr}_{2} \mathrm{MgMoO}_{6-\delta}$ at equilibrium with the $800{ }^{\circ} \mathrm{C}$ reducing atmosphere, whereas the higher value may be a result of the presence of a small amount of $\mathrm{SrMoO}_{3}$, perhaps on the surface.

Whereas for most of the materials, the conductivity measurements were stable with time, the $\mathrm{Ni}$ and Co variant double-perovskites, SNM and SCM, exhibited anomalous conductivity behavior in reducing atmospheres. Both materials were sintered in air and exposed to various reducing atmospheres at $800{ }^{\circ} \mathrm{C}$. The electrical conductivity of SNM varied from 0.1 to $250 \mathrm{~S} / \mathrm{cm}$ depending on the reducing atmosphere and length of time the material was reduced (reaching $250 \mathrm{~S} / \mathrm{cm}$ only after $300 \mathrm{~h}$ in dry $9 \% \mathrm{H}_{2} / \mathrm{Ar}$ with a $\mathrm{pO}_{2}$ of $\left.10^{-23} \mathrm{~atm}\right)$. SCM took a similar long time to fully reduce and reached $100 \mathrm{~S} / \mathrm{cm}$. The question arises, how can an order of magnitude greater conductivity than $\mathrm{Sr}_{2} \mathrm{MgMoO}_{6}(>100$ vs $10 \mathrm{~S} / \mathrm{cm})$ be possible with the same oxygenvacancy $\mathrm{Mo}^{5+/ 6+}$ mechanism described earlier? While conducting the present study, Wei et al [70] and Huang et al [71] reported wide-ranging conductivity results for SNM but did not explain them. In the present study, we found that both SNM and SCM decompose to multiple phases, including $\mathrm{SrMoO}_{3}, \mathrm{Sr}_{3} \mathrm{MoO}_{6}, \mathrm{Sr}_{2} \mathrm{MoO}_{4}$ and precipitated nano-particles of $\mathrm{Ni}$ and $\mathrm{MoNi}_{4}$, in strong reducing atmospheres. The nano-particles precipitate as chains at the grain boundaries in the bulk material (Figure 6) and all over the surfaces of the host SNM material (not shown). The resulting multi-phase composite has higher conductivity than SNM and apparently reaches an equilibrium distribution of phases after several hundred hours at $800{ }^{\circ} \mathrm{C}$. Using the Mo-O phase diagram shown earlier and those for $\mathrm{Ni}-\mathrm{O}$ and $\mathrm{Co}-\mathrm{O}$ (not shown) as guidelines to the phase stability of the double-perovskites, decomposition is not unexpected since the metals (Mo, Ni, and Co) are favored at the strong reducing conditions applied.

This reduction-decomposition can explain the increasing conductivity and the wide range of conductivity results in literature that were thought to be due only to the formation of oxygen vacancies and corresponding partial reduction of $\mathrm{Mo}^{6+}$ to $\mathrm{Mo}^{5+}$. From an application standpoint this decomposition is not necessarily disadvantageous. Precipitation of $\mathrm{Ni}$ or $\mathrm{Pd}$ metal particles from titanate ceramics in a reducing atmosphere has been exploited in catalysis [72-76], and precipitation of $\mathrm{Ni}$ or $\mathrm{Ru}$ metal particles from chromite ceramic solid oxide cell anodes has been observed [77, 78], but not decomposition to this extent to form a composite of multiple useful phases with an entirely nanostructured surface. Adding Ti to the B-site, as $\mathrm{SrTi}_{0.5} \mathrm{Ni}_{0.25} \mathrm{Mo}_{0.25} \mathrm{O}_{3}$, prevented decomposition and reduced the total conductivity that could be attained, which shows that the extent of decomposition can be controlled by modifying the composition. The mechanism of the decomposition and further details of conductivity, phase stability and microstructure will be reported in a future article. 

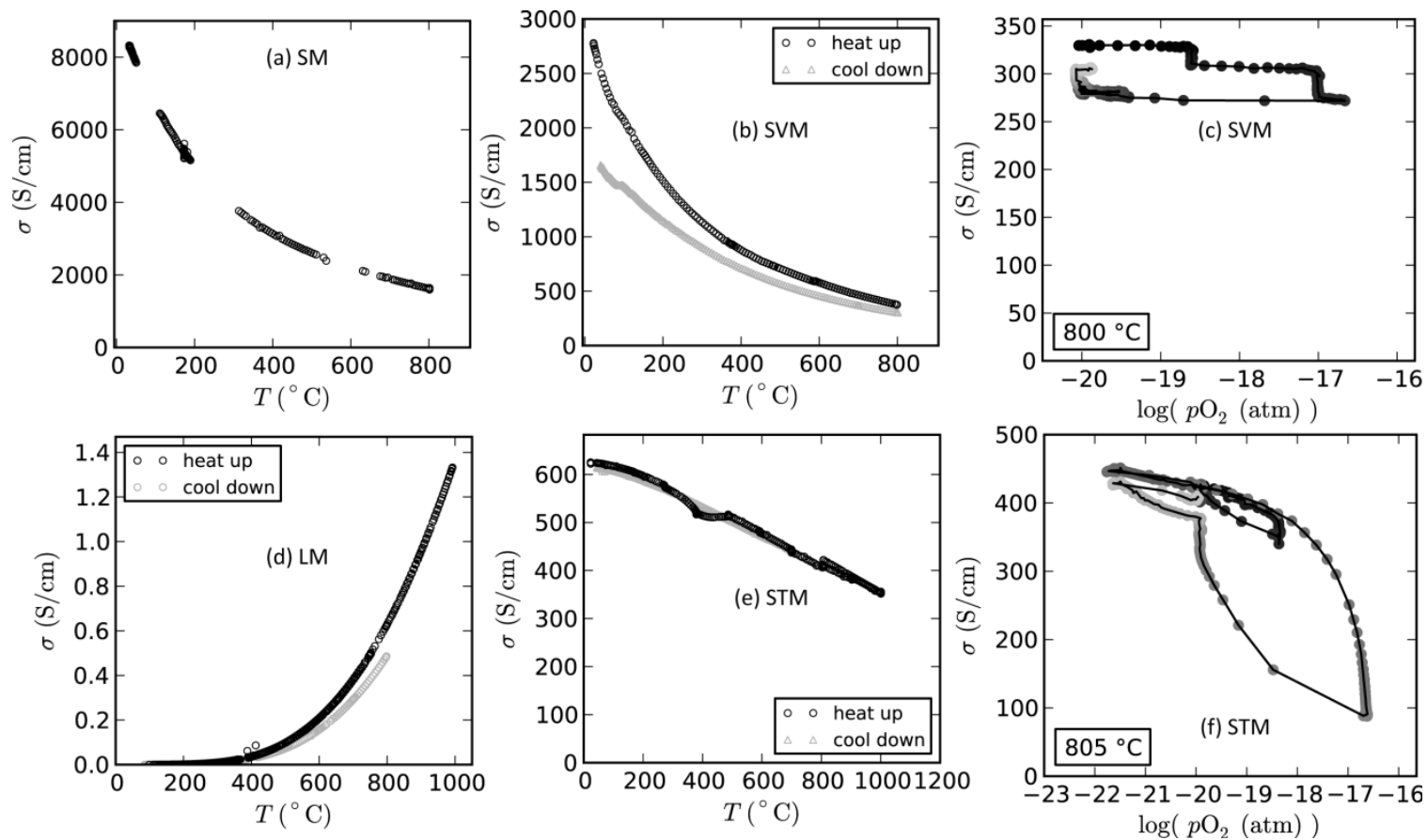

Figure 4. Electrical conductivity versus temperature or $p \mathrm{O}_{2}$ for (a) $\mathrm{SM}$, (b,c) $\mathrm{SVM}$, (d) $\mathrm{LM}$, and $(\mathrm{e}, \mathrm{f}) \mathrm{STM}$. In the $p \mathrm{O}_{2}$ graphs $(\mathrm{c}, \mathrm{f})$, one point was measured every 3 minutes and the shading of the points changes from black to light gray with time.
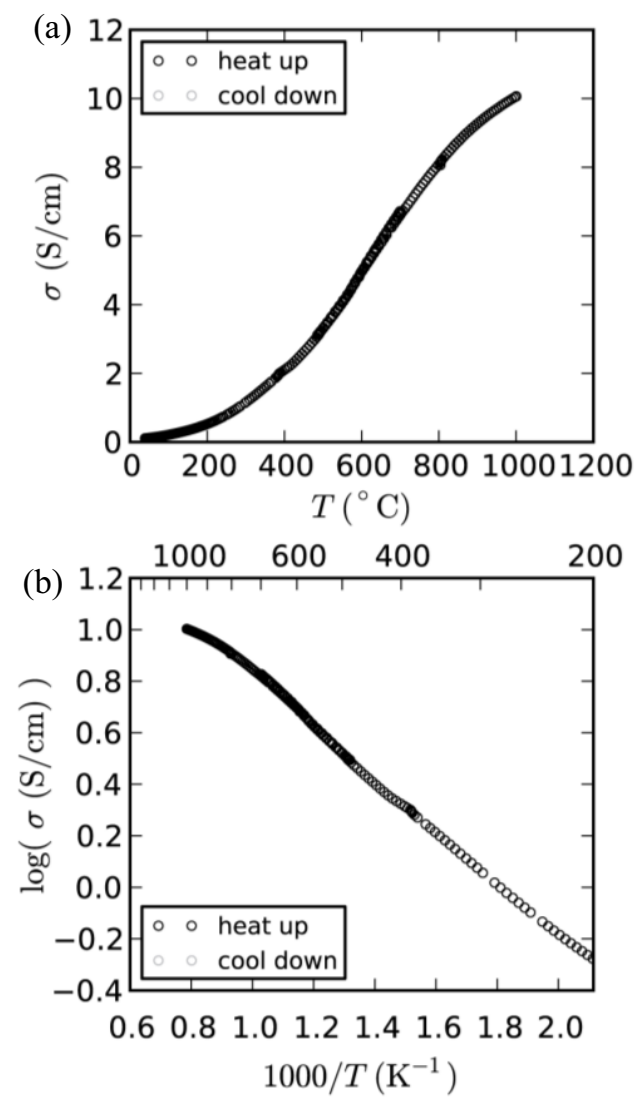

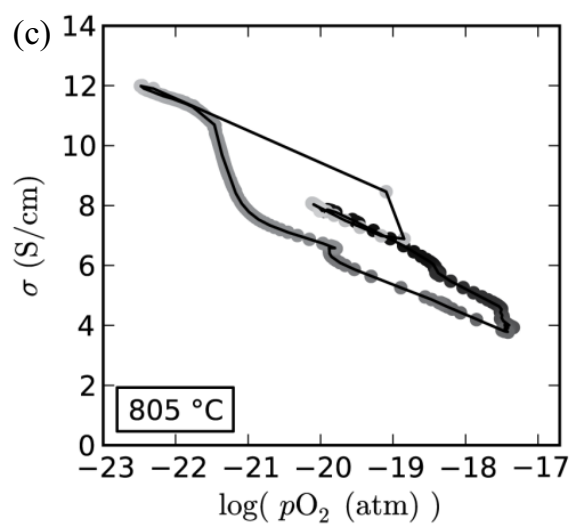

Figure 5. Electrical conductivity measurements of the reducing-sintered $\mathrm{Sr}_{2} \mathrm{MgMoO}_{6}$ sample SMM_2. 


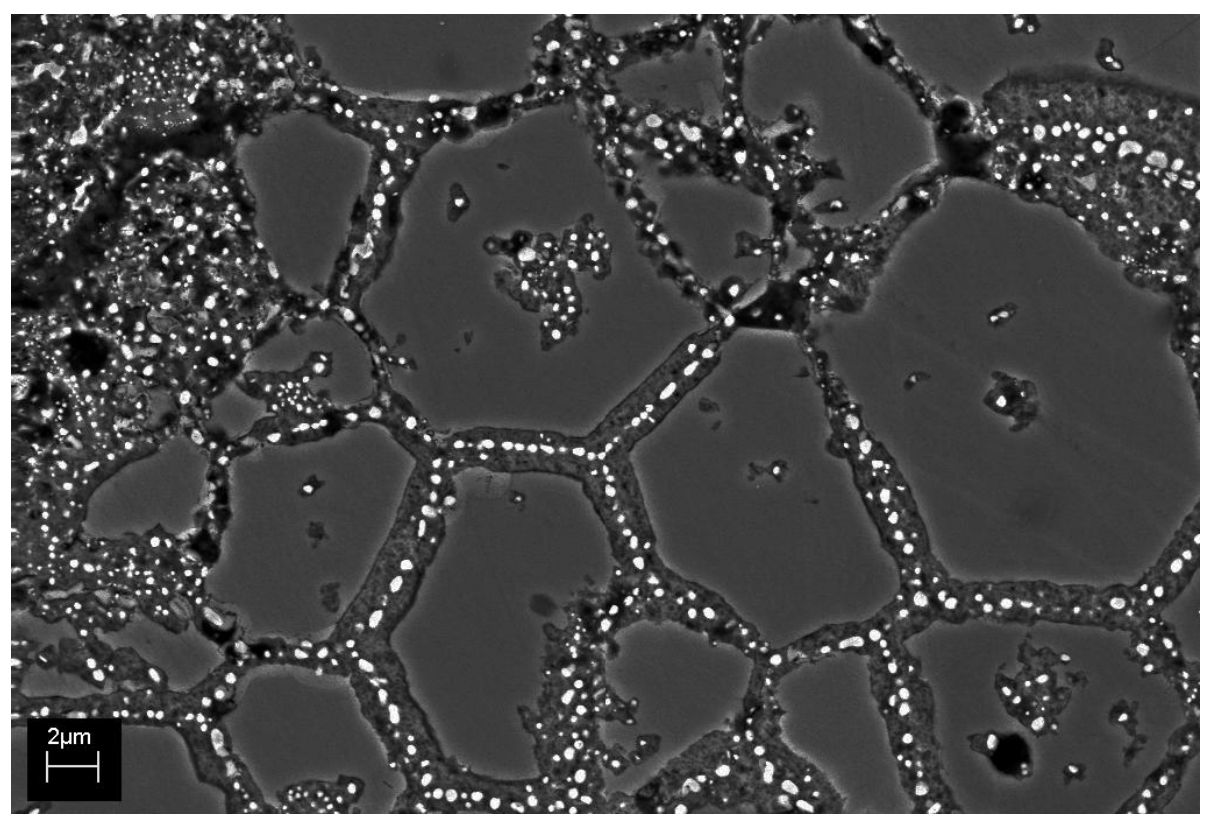

Figure 6. SEM micrograph of the SNM polished surface after the conductivity test, with the backscatter detector.

The conductivity of the Fe-variant SFM was higher than any of the other doubleperovskites (Figure 7), in agreement with reports in literature $[34,79]$. Its conductivity was metallic type, and stable up to $1000{ }^{\circ} \mathrm{C}\left(800{ }^{\circ} \mathrm{C}\right.$ with $p \mathrm{O}_{2}=10^{-23}$ atm was held for $68 \mathrm{~h}$, and $1000{ }^{\circ} \mathrm{C}_{\mathrm{pO}_{2}}=10^{-18.5}$ atm was held for $3 \mathrm{~h}$ ), suggesting that the conductivity mechanism is not the same as that for SMM, SNM and SCM. SFM has different properties because the Fe-Mo ion couple is mixed-valent for both ions $\left(\mathrm{Fe}^{2+/ 3+}\right.$ and $\mathrm{Mo}^{5+/ 6+}$ ), according to literature [80]. This mixed-valency enhances the electronic conductivity [81]. It has been proposed that metallic conductivity in a double perovskite depends on the $3+/ 5+$ couple [82].

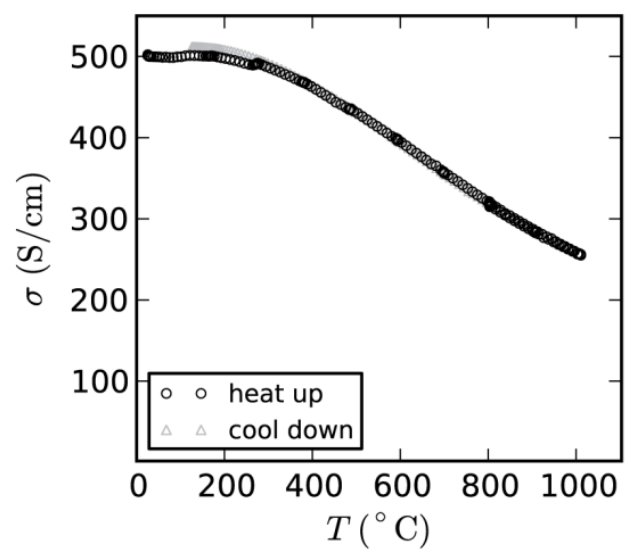

Figure 7. Electricity conductivity of $\mathrm{Sr}_{2} \mathrm{FeMoO}_{6}$ in dry $9 \% \mathrm{H}_{2} / \mathrm{Ar}$.

Finally, the conductivity of the tungstates was measured and was found to be $<0.01 \mathrm{~S} / \mathrm{cm}$ for both materials, SMW and SNW. In literature, the Fe-variant SFW, has been reported as an insulator [83, 84]. The insulating nature of $\mathrm{W}$ versus Mo can be explained by the relatively higher stability of $\mathrm{Mo}^{5+}$ versus $\mathrm{W}^{5+}$ [79]. This most likely relates to the narrow region of stability of $\mathrm{W}^{4+}$ as well, seen in the phase diagram earlier 
(Figure 1). Due to such a low conductivity, the tungstates could not be further studied as electrode materials.

\section{Electrochemical Activity for $\mathrm{H}_{2} \underline{O} / \mathrm{CO}_{2}$ Electrolysis and $\mathrm{H}_{2} /$ CO Oxidation}

The electrochemical activity of the molybdate materials was investigated using point-contact electrodes. A series of experiments were performed to determine the best geometry and method to estimate the TPB length. Even if some of the materials exhibit mixed conductivity, the TPB length is still the most useful normalization parameter. An example of the contact area for one of the electrodes is shown in Figure 8. The area and perimeter were measured and used to apply correction factors to the area and TPB estimated by the Newman relation (from the serial resistance $\mathrm{R}_{\mathrm{S}}$ ). The measurements on different electrodes of the same material were reproducible within $\sim 50 \%$, which is sufficient for this quick test and considering that the performance of the different materials spans orders of magnitude. Since none of the electrodes exhibited a rapidly and/or constantly increasing $\mathrm{R}_{\mathrm{S}}$ which would be indicative of the formation of an insulating layer, none of the electrodes were strongly reactive with YSZ at the operating conditions $\left(700-850{ }^{\circ} \mathrm{C}\right)$. SMM has been reported to react with YSZ at higher temperatures [85].

Example impedance spectra measured at OCV are shown in Figure 9. A detailed analysis of the IS was not carried out in the present study. The IS were used only to determine $R_{S}$ and $R_{P}$ to assess the relative performance of the materials. From these spectra one can see that SFM has much higher performance than STM for all atmospheres. Furthermore, the difference in performance in $\mathrm{CO} / \mathrm{CO}_{2} \mathrm{vs} \mathrm{H}_{2} / \mathrm{H}_{2} \mathrm{O}$ is much greater for STM than for SFM.

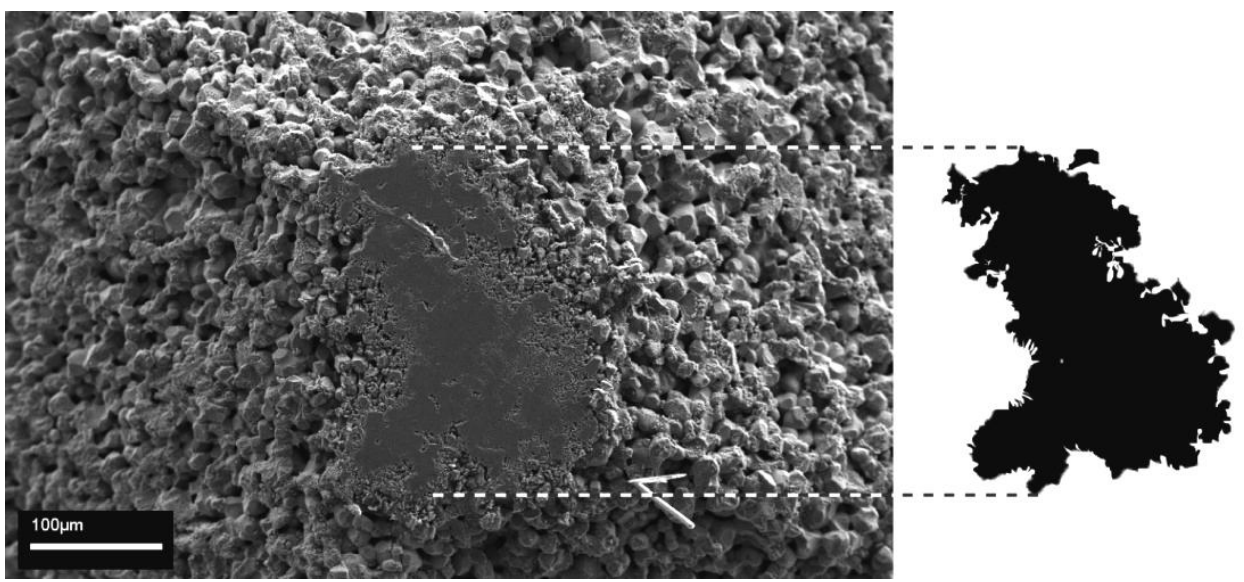

Figure 8. Contact area of the tip of an SFM cone type electrode that had been in contact with the smooth polished YSZ surface. The outline of the measured contact area is shown at the right.

The relative performance, as the length-specific polarization resistance $\left(\mathrm{LSR}_{\mathrm{P}}\right)$ measured at OCV, of all of the materials tested, is shown in Figure 10. The $\mathrm{LSR}_{\mathrm{P}}$ values are averages between multiple electrodes when multiple electrodes of a single material were tested. For SM, only the $\mathrm{LSR}_{\mathrm{P}}$ in $3 \% \mathrm{H}_{2} \mathrm{O} / \mathrm{H}_{2}$ is given, because the material oxidized to $\mathrm{SrMoO}_{4}$ upon switching to $50 \% \mathrm{H}_{2} \mathrm{O} / \mathrm{H}_{2}$. From the rest of the results, one can see that SFM and the pre-reduced SNM materials have the highest electrocatalytic activity in the OCV measurements. The SMM electrode was made of the air-sintered 
material, so even though it was pre-reduced at $800{ }^{\circ} \mathrm{C}$ in dry $9 \% \mathrm{H}_{2} / \mathrm{Ar}$, its electrochemical performance was most likely lower than it would be for a reducingsintered sample. For all of the electrodes, $\mathrm{LSR}_{\mathrm{P}}$ in $3 \% \mathrm{H}_{2} \mathrm{O} / \mathrm{H}_{2}$ is lower than or equal to $\mathrm{LSR}_{\mathrm{P}}$ in $50 \% \mathrm{H}_{2} / \mathrm{H}_{2}$. Most likely this can be attributed to the fact that $3 \% \mathrm{H}_{2} \mathrm{O} / \mathrm{H}_{2}$ is a more reducing atmosphere, which more strongly reduces the ceramic materials at least at the surfaces, leading to oxygen loss and a higher concentration of electrons and oxygen vacancies. SEM inspection of the electrode surfaces after testing showed the nanostructured surfaces described in the last section, for SNM and SCM.

Another noteworthy observation is that, whereas most of the materials have significantly lower performance in $50 \% \mathrm{CO}_{2} / \mathrm{CO}$ than in $50 \% \mathrm{H}_{2} \mathrm{O} / \mathrm{H}_{2}, \mathrm{SVM}$ has almost the exact same performance, which suggests that $\mathrm{V}$ may be a good catalyst for the $\mathrm{CO} / \mathrm{CO}_{2}$ reactions. At the other extreme, the much lower performance of $\mathrm{SCM}$ in $\mathrm{CO} / \mathrm{CO}_{2}$ than in $\mathrm{H}_{2} / \mathrm{H}_{2} \mathrm{O}$ suggests that $\mathrm{Co}$ may not be a desirable catalyst for $\mathrm{CO} / \mathrm{CO}_{2}$ reactions. Finally, also marked on the plot is the $\mathrm{LSR}_{\mathrm{P}}$ range obtained for donor-doped strontium titanates such as $\mathrm{Sr}_{0.94} \mathrm{Ti}_{0.9} \mathrm{Nb}_{0.1} \mathrm{O}_{3}, \mathrm{La}_{0.35} \mathrm{Sr}_{0.65} \mathrm{TiO}_{3}, \mathrm{Y}_{0.08} \mathrm{Sr}_{0.92} \mathrm{TiO}_{3}$, and $\mathrm{Y}_{0.08} \mathrm{Sr}_{0.88} \mathrm{TiO}_{3}$ which were synthesized by solid state reaction and tested similarly as cone-shaped electrodes. Although these titanates are known to provide poor performance as electrode materials, the fact that the new materials have 2 orders of magnitude lower $\mathrm{LSR}_{\mathrm{P}}$ values suggests that they are very promising electrocatalysts.
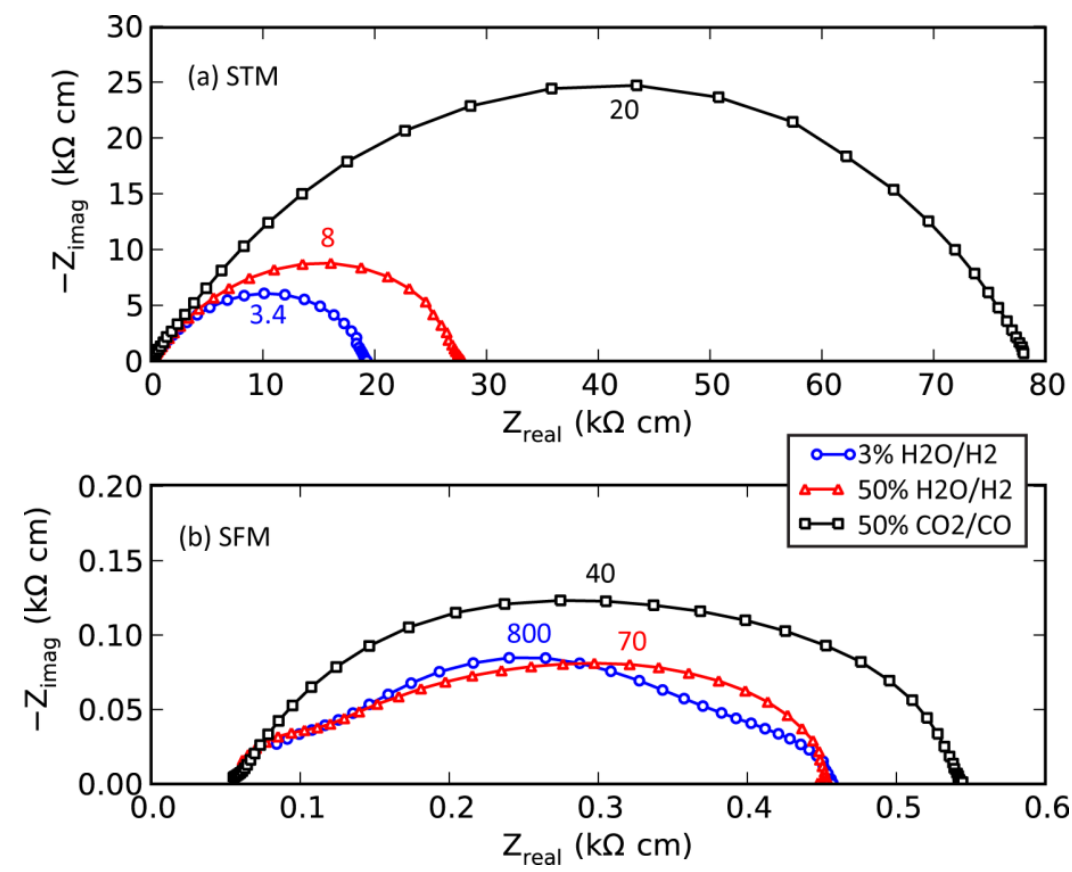

Figure 9. Example impedance spectra measured at OCV at $850{ }^{\circ} \mathrm{C}$ on (a) one of the STM electrodes, and (b) one of the SFM electrodes. The numbers near each peak are the approximate summit frequency in $\mathrm{Hz}$.

Potential sweeps were performed on all of the electrodes in $50 \% \mathrm{H}_{2} \mathrm{O} / \mathrm{H}_{2}$. Only one is shown as an example - that for SVM (Figure 11). Cathodic polarization $\left(\mathrm{H}_{2} \mathrm{O}\right.$ electrolysis, in this case) significantly activates the electrode relative to OCV. The instantaneous slope of the polarization curve at $-200 \mathrm{mV}$ vs at OCV, determined by IS measured under bias, was about $0.8 \mathrm{k} \Omega \mathrm{cm}$ vs $10 \mathrm{k} \Omega \mathrm{cm}$, or a factor of 12 lower $\mathrm{LSR}_{\mathrm{P}}$. $200 \mathrm{mV}$ is chosen because this magnitude of cathodic bias is relevant for electrolysis cell operation - the total overpotential, including the potential drop at the positive-electrode 
and the ohmic drop across the electrolyte, should be $500-700 \mathrm{mV}$ for electrolysis at $850{ }^{\circ} \mathrm{C}$ if operating at the thermoneutral voltage. Clearly, OCV $\mathrm{R}_{\mathrm{P}}$ values are not always indicative of the true performance of these molybdates (as well as some other ceramics e.g. titanates $[45,86])$. Some ceramic materials activate during reduction, most likely because reducing them leads to defect chemistry changes on the surface of the material, such as oxygen loss and an increase in surface oxygen vacancy concentration. Not all of the electrodes activated so significantly during cathodic polarization; for others the potential sweeps were more linear. Details of the potential sweeps will be described in the future.

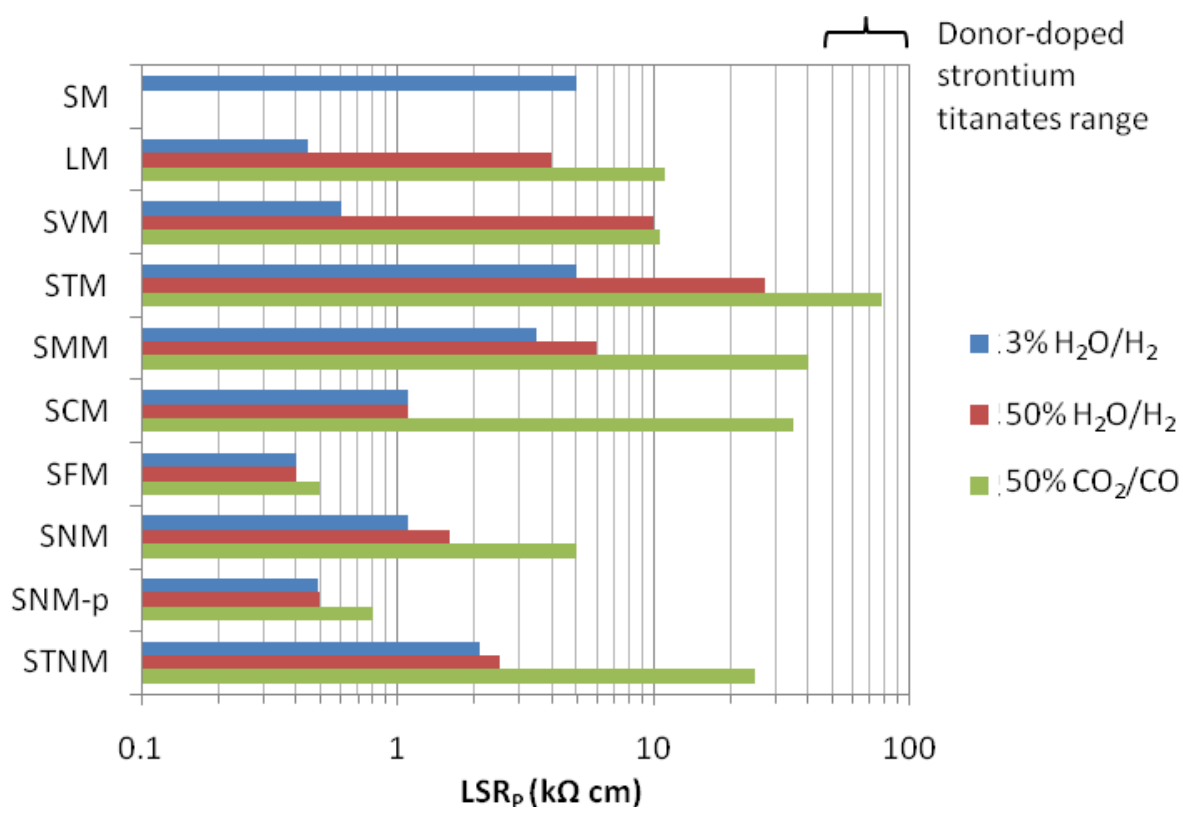

Figure 10. Relative electrochemical performance of the tested materials, in terms of the $\mathrm{LSR}_{\mathrm{P}}$ at $\mathrm{OCV}$ in $3 \% \mathrm{H}_{2} \mathrm{O} / \mathrm{H}_{2}, 50 \% \mathrm{H}_{2} \mathrm{O} / \mathrm{H}_{2}$, and $50 \% \mathrm{CO}_{2} / \mathrm{CO}$. SNM-p = pre-reduced SNM.

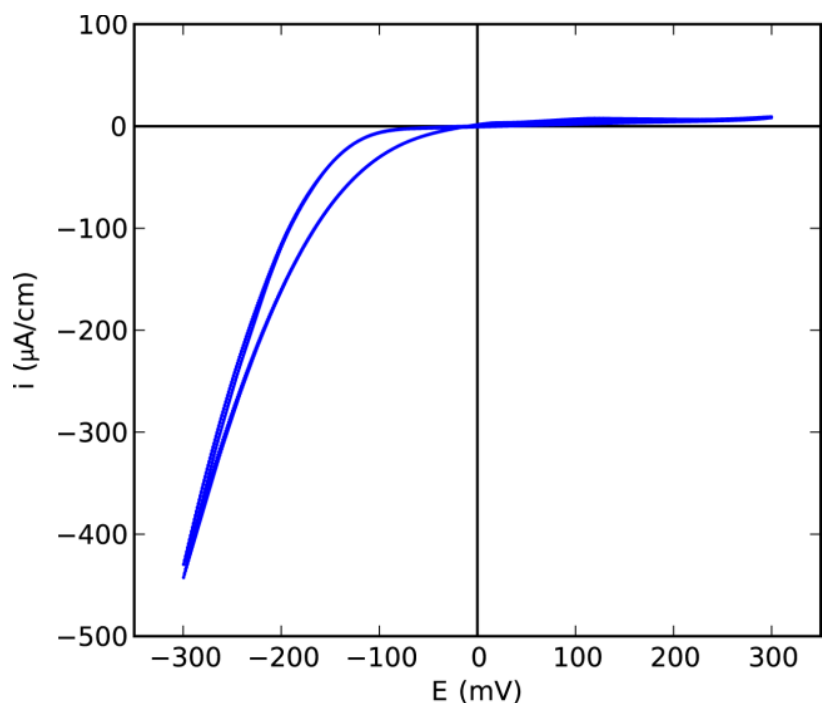

Figure 11. Potential sweep on the SVM electrode, at $2 \mathrm{mV} / \mathrm{s}$ at $850{ }^{\circ} \mathrm{C}$ in $50 \% \mathrm{H}_{2} \mathrm{O} / \mathrm{H}_{2}$. The sweep was repeated 3 times. The 3 cycles nearly overlaid each other. 
The high performance of SNM is most likely due to the nanostructured surface and precipitated nanoparticles discussed earlier. SFM, on the other hand, does not seem to decompose in such a way, yet has even higher performance. The stability can be attributed to the greater stability of $\mathrm{Fe}$ against reduction to metal than $\mathrm{Ni}$ and $\mathrm{Co}$, and the high performance may be related to the defect chemistry of SFM. A higher concentration of oxygen vacancies may be present in the material. In catalysis, SFM was observed to provide high catalytic performance for $\mathrm{CH}_{4}$ oxidation and this high performance was attributed to a high concentration of oxygen vacancies [87]. As discussed earlier, oxygen vacancies form in reduced $\mathrm{SMM}$ as a result of some of the $\mathrm{Mo}^{6+}$ ions accepting an electron and becoming $\mathrm{Mo}^{5+}$. In SFM, the Fe ions most likely are mixed-valent as well $\left(\mathrm{Fe}^{2+/ 3+}\right)$, which might allow for yet more oxygen vacancies in the crystal lattice.

\section{Conclusions}

In this study, a number of Mo-based ceramics were studied for their fundamental properties of phase, microstructure and electronic conductivity, and they were tested as solid oxide cell negative-electrodes using simplified geometry point-contact electrodes. The conductivity of many of the materials depended significantly on the thermal history. The results show that molybdenum can be used on the B-site of a variety of ceramic materials that have high electrochemical performance for $\mathrm{H}_{2} \mathrm{O} / \mathrm{CO}_{2}$ reduction and $\mathrm{H}_{2} / \mathrm{CO}$ oxidation. Most of the rich properties that Mo-based ceramics have to offer seem to be related to the valence flexibility of the Mo ion. These Mo-based ceramics can provide high electronic conductivity, high electrocatalytic activity, and mixed ionic-electronic conductivity via oxygen vacancies (which also often enhances the electrocatalytic activity). Many of the materials were significantly activated by cathodic polarization, and they exhibited higher performance for cathodic (electrolysis) polarization than anodic (fuel cell) polarization, which makes them especially interesting for electrolysis electrodes.

For some materials such as the double-perovskites $\mathrm{Sr}_{2} \mathrm{NiMoO}_{6}$ and $\mathrm{Sr}_{2} \mathrm{CoMoO}_{6}$, a decomposition phenomenon that leads to a unique nanostructured surface and multiple desirable electrocatalytic and electron-conductive phases was observed under operating conditions (certain reducing atmospheres). The material was reduced and decomposed in a beneficial way, precipitating $\mathrm{Ni}$ and $\mathrm{Ni}-\mathrm{Mo}$ nanoparticles to the surface and grain boundaries and forming other ceramic phases with high electronic conductivity. This phenomenon explains the wide range of electrical conductivity results reported in literature. Preparing a material by performing controlled formation/decomposition of multiple desirable phases and a desirable microstructure (which can take place in situ) using these materials is a new way to produce potentially high-performance electrodes or electrode components for solid oxide cells.

By modifying the composition (adding Ti to the B-site), it was possible to prevent decomposition. Another member of the double-perovskite molybdate family, $\mathrm{Sr}_{2} \mathrm{FeMoO}_{6}$, exhibited similarly high electronic conductivity and electrocatalytic activity but did not decompose. The high activity was the result of a different mechanism (besides a nanostructured surface), probably related to the defect chemistry of the material (possibly high mixed ionic-electronic conductivity) and/or the mixed valency of the Fe and Mo ions.

In terms of the stability of molybdate based materials, Mo needs a partner. If a redox-stable or nearly redox-stable material is desired, one must allow the fully oxidized 
valence of $6+$. Alternatively, if one can deal with reversible phase changes accompanied by large volume expansion and contraction (as with $\mathrm{Ni}-\mathrm{NiO}$ in conventional electrodes), one can use Mo with 4+ valence.

\section{Acknowledgments}

The authors wish to thank Konrad Tarka for help with sample preparation. Acknowledgment is made to the Donors of the American Chemical Society Petroleum Research Fund for partial support of this research, as well as the Programme Commission on Sustainable Energy and Environment, The Danish Council for Strategic Research, via the SERC project (www.serc.dk).

\section{References}

1. S.D. Ebbesen and M. Mogensen, Electrochem. Solid-State Lett. 13 (9) B106 (2010)

2. M. Ettler, H. Timmermann, J. Malzbender, A. Weber and N.H. Menzler, J. Power Sources 195 (17) 5452 (2010)

3. B.C.H. Steele, Solid State Ionics 86-88 (Part 2) 1223 (1996)

4. J.W. Fergus, Solid State Ionics 177 (17-18) 1529 (2006)

5. J.B. Goodenough and Y.H. Huang, J. Power Sources 173 (1) 1 (2007)

6. J.T.S. Irvine, In: T. Ishihara, Editor, Perovskite Oxide for Solid Oxide Fuel Cells (2009), pp. 167-182.

7. S. Park, J.M. Vohs and R.J. Gorte, Nature 404 (6775) 265 (2000)

8. P. Blennow, Strontium Titanate-based Anodes for Solid Oxide Fuel Cells, Lund University (2007), p. 209.

9. J.B. Goodenough, Reports on Progress in Physics 67 (11) 1915 (2004)

10. P. Lacorre, F. Goutenoire, O. Bohnke, R. Retoux and Y. Laligant, Nature 404 (6780) 856 (2000)

11. O. Porat, C. Heremans and H.L. Tuller, Solid State Ionics 94 (1-4) 75 (1997)

12. Y.-H. Huang, R.I. Dass, J.C. Denyszyn and J.B. Goodenough, J. Electrochem. Soc. 153 (7) A1266 (2006)

13. Y.-H. Huang, R.I. Dass, Z.-L. Xing and J.B. Goodenough, Science 312 (5771) 254 (2006)

14. Y. Ji, Y.-H. Huang, J.-R. Ying and J.B. Goodenough, Electrochem. Commun. 9 (8) 1881 (2007)

15. D. Marrero-Lopez, J. Pena-Martinez, J.C. Ruiz-Morales, D. Perez-Coll, M.A.G. Aranda and P. Nunez, Mater. Res. Bull. 43 (8-9) 2441 (2008)

16. D. Marrero-López, J. Peña-Martínez, J.C. Ruiz-Morales, M.C. Martín-Sedeño and P. Núñez, J. Solid State Chem. 182 (5) 1027 (2009)

17. L. Kong, B. Liu, J. Zhao, Y. Gu and Y. Zhang, J. Power Sources 188 (1) 114 (2009)

18. X.C. Lu and J.H. Zhu, J. Electrochem. Soc. 155 (10) B1053 (2008)

19. M. Greenblatt, In: C. Schlenker, Editor, Physics and chemistry of low-dimensional inorganic conductors (1996), p. 15.

20. Y. Xue, Y. Zhang and P. Zhang, Physical Review B (Condensed Matter and Materials Physics) 79 (20) 205113 (2009)

21. E.J. Huibregtse, D.B. Barker and G.C. Danielson, Physical Review 84 (1) 142 (1951)

22. N. Garif'yanov, S. Khlebnikov, I. Khlebnikov and I. Garifullin, Czech J. Phys. 46 (0) 855 (1996)

23. L.H. Brixner, Journal of Inorganic and Nuclear Chemistry 14 (3-4) 225 (1960)

24. T. Maekawa, K. Kurosaki, H. Muta, M. Uno and S. Yamanaka, J. Alloys Compd. 390 (12) 314 (2005)

25. L.M. Madeira, M.F. Portela and C. Mazzocchia, Catalysis Reviews: Science and Engineering 46 (1) 53 (2004)

26. A. Katrib, P. Leflaive, L. Hilaire and G. Maire, Catal. Lett. 38 (1) 95 (1996) 
27. J. Kubo and W. Ueda, Mater. Res. Bull. 44 (4) 906 (2009)

28. R. Schulz, J.Y. Huot, M.L. Trudeau, L. Dignardbailey, Z.H. Yan, S. Jin, A. Lamarre, E. Ghali and A. Vanneste, J. Mater. Res. 9 (11) 2998 (1994)

29. A. Kawashima, E. Akiyama, H. Habazaki and K. Hashimoto, Elsevier Science Sa Lausanne (1997), pp. 905-909.

30. K. Hashimoto, T. Sasaki, S. Meguro and K. Asami, Materials Science and Engineering A 375-377 942 (2004)

31. FactSage 5.5 software.

32. M. Itoh, I. Ohta and Y. Inaguma, Materials Science and Engineering B 41 (1) 55 (1996)

33. M.C. Viola, M.J. Martinez-Lope, J.A. Alonso, P. Velasco, J.L. Martinez, J.C. Pedregosa, R.E. Carbonio and M.T. Fernandez-Diaz, Chem. Mater. 14 (2) 812 (2002)

34. J.B. Shi, P.H. Peng, Y.Y. Fan, C.Y. Lee, W.T. Lai, H.C. Ku, H.Z. Chen and S.L. Young, Physica B: Condensed Matter 329-333 (Part 2) 731 (2003)

35. Y. Teraoka, M.D. Wei and S. Kagawa, J. Mater. Chem. 8 (11) 2323 (1998)

36. R.D. Shannon, Acta Cryst. A32 751 (1976)

37. C. Graves, S.D. Ebbesen and M. Mogensen, ECS Trans. 25 (2) 1945 (2009)

38. M. Odgaard and E. Skou, Solid State Ionics 86-8 1217 (1996)

39. R. Baker, J. Guindet and M. Kleitz, J. Electrochem. Soc. 144 (7) 2427 (1997)

40. K. Kammer and M. Mogensen, In: A.S. S. Linderoth, N. Bonanos, A. Hagen, L. Mikkelsen, K. Kammer, D. Lybye, P.V. Hendriksen, F.W. Poulsen, M. Mogensen, W.G. Wang, Editor, The 26th Risø International Symposium on Materials Science: Solid State Electrochemistry, Risø National Laboratory, Roskilde, Denmark (2005).

41. K. Kammer, Solid State Ionics 177 (11-12) 1047 (2006)

42. P. Blennow, K.K. Hansen, L.R. Wallenberg and M. Mogensen, Electrochim. Acta 52 (4) 1651 (2006)

43. K.K. Hansen, Electrochem. Commun. 9 (11) 2721 (2007)

44. K.K. Hansen and M. Mogensen, ECS Trans. 13 (26) 153 (2008)

45. P. Blennow, K.K. Hansen, L.R. Wallenberg and M. Mogensen, Solid State Ionics 180 (1) 63 (2009)

46. K. Kamata, T. Nakamura and T. Sata, Mater. Res. Bull. 10 (5) 373 (1975)

47. S. Hayashi, R. Aoki and T. Nakamura, Mater. Res. Bull. 14 (3) 409 (1979)

48. R. Agarwal, Z. Singh and V. Venugopal, J. Alloys Compd. 282 (1-2) 231 (1999)

49. S. Yamanaka, K. Kurosaki, T. Maekawa, T. Matsuda, S.-i. Kobayashi and M. Uno, J. Nucl. Mater. 344 (1-3) 61 (2005)

50. G.M. Veith, M. Greenblatt, M. Croft, K.V. Ramanujachary, J. Hattrick-Simpers, S.E. Lofland and I. Nowik, Chem. Mater. 17 (10) 2562 (2005)

51. A. Prasatkhetragarn, P. Ketsuwan, S. Maensiri, R. Yimnirun, C.C. Huang and D.P. Cann, J. Appl. Phys. 106 (9) 4 (2009)

52. L.H. Brixner, Journal of Inorganic and Nuclear Chemistry 15 (3-4) 356 (1960)

53. V.A. Fotiev, G.V. Bazuev and V.G. Zubkov, Inorganic Materials 23 (6) 895 (1987)

54. P. Karen, A.R. Moodenbaugh, J. Goldberger, P.N. Santhosh and P.M. Woodward, J. Solid State Chem. 179 (7) 2120 (2006)

55. E.J. Fresia, L. Katz and R. Ward, J. Am. Chem. Soc. 81 (18) 4783 (1959)

56. S. Nomura and T. Nakagawa, J. Phys. Soc. Jpn. 21 (6) 1068 (1966)

57. M. Gateshki and J.M. Igartua, J. Phys.: Condens. Matter 16 (37) 6639 (2004)

58. M.W. Lufaso, R.B. Macquart, Y. Lee, T. Vogt and H.-C.z. Loye, J. Phys.: Condens. Matter 18 (39) 8761 (2006)

59. S.A. Ivanov, S.G. Eriksson, R. Tellgren, H. Rundlof and M. Tssegai, (2006), pp. $537-$ 542.

60. A.K. Eriksson, S.G. Eriksson, S.A. Ivanov, C.S. Knee, J. Eriksen, H. Rundlöf and M. Tseggai, Mater. Res. Bull. 41 (1) 144 (2006)

61. I. Nagai, N. Shirakawa, S.-i. Ikeda, R. Iwasaki, H. Nishimura and M. Kosaka, Appl. Phys. Lett. 87 (2) 024105 (2005) 
62. B.C. Zhao, Y.P. Sun, S.B. Zhang, X.B. Zhu and W.H. Song, J. Cryst. Growth 290 (1) 292 (2006)

63. H.H. Wang, D.F. Cui, Y.L. Zhou, Z.H. Chen, F. Chen, T. Zhao, H.B. Lu, G.Z. Yang, M.C. Xu, Y.C. Lan, X.L. Chen, H.J. Qian and F.Q. Liu, J. Cryst. Growth 226 (2-3) 261 (2001)

64. A. Aguadero, C. de la Calle, J.A. Alonso, D. Pérez-Coll, M.J. Escudero and L. Daza, J. Power Sources 192 (1) 78 (2009)

65. Y.C. Lan, X.L. Chen and M. He, J. Alloys Compd. 354 (1-2) 95 (2003)

66. T. Maekawa, K. Kurosaki and S. Yamanaka, J. Alloys Compd. 426 (1-2) 46 (2006)

67. A. Atkinson, S. Barnett, R.J. Gorte, J.T.S. Irvine, A.J. McEvoy, M. Mogensen, S.C. Singhal and J. Vohs, Nat. Mater. 3 (1) 17 (2004)

68. M.D. Gross, J.M. Vohs and R.J. Gorte, Electrochemical and Solid State Letters 10 (4) B65 (2007)

69. J.L. MacManus-Driscoll, A. Sharma, Y. Bugoslavsky, W. Branford, L.F. Cohen and M. Wei, Advanced Materials 18 (7) 900 (2006)

70. T. Wei, Y. Ji, X. Meng and Y. Zhang, Electrochem. Commun. 10 (9) 1369 (2008)

71. Y.-H. Huang, G. Liang, M. Croft, M. Lehtimäki, M. Karppinen and J.B. Goodenough, Chem. Mater. 21 (11) 2319 (2009)

72. T. Hayakawa, A.G. Andersen, M. Shimizu, K. Suzuki and K. Takehira, Catal. Lett. 22 (4) 307 (1993)

73. T. Hayakawa, H. Harihara, A.G. Andersen, A.P.E. York, K. Suzuki, H. Yasuda and K. Takehira, Angewandte Chemie International Edition in English 35 (2) 192 (1996)

74. S. Suzuki, T. Hayakawa, S. Hamakawa, K. Suzuki, T. Shishido and K. Takehira, In: A. Parmaliana, D. Sanfilippo, F. Frusteri, A. Vaccari and F. Arena, Editors, Natural Gas Conversion V(1998), pp. 783-788.

75. Y. Nishihata, J. Mizuki, T. Akao, H. Tanaka, M. Uenishi, M. Kimura, T. Okamoto and N. Hamada, Nature 418 (6894) 164 (2002)

76. H. Tanaka, I. Tan, M. Uenishi, M. Taniguchi, M. Kimura, Y. Nishihata and J. Mizuki, J. Alloys Compd. 4081071 (2006)

77. B.D. Madsen, W. Kobsiriphat, Y. Wang, L.D. Marks and S.A. Barnett, J. Power Sources 166 (1) 64 (2007)

78. W. Kobsiriphat, B.D. Madsen, Y. Wang, M. Shah, L.D. Marks and S.A. Barnett, J. Electrochem. Soc. 157 (2) B279 (2010)

79. B. Chattopadhyay, A. Poddar, S. Das, C. Majumder and R. Ranganathan, J. Alloys Compd. 366 (1-2) 28 (2004)

80. A.W. Sleight and J.F. Weiher, J. Phys. Chem. Solids 33 (3) 679 (1972)

81. A. Azizi, A. Kahoul, G. Schmerber, S. Colis and A. Dinia, International Journal of Modern Physics B 22 (21) 3579 (2008)

82. T. Hirama, N. Tsujii, H. Kitazawa and G. Kido, Physica B: Condensed Matter 359-361 $1336(2005)$

83. N.E. Massa, J.A. Alonso, M.J. Martínez-Lope and M.T. Casais, Physical Review B 72 (21) 214303 (2005)

84. E. Carvajal, O. Navarro, R. Allub, M. Avignon and B. Alascio, physica status solidi (b) 242 (9) 1942 (2005)

85. D. Marrero-López, J. Peña-Martínez, J.C. Ruiz-Morales, M. Gabás, P. Núñez, M.A.G. Aranda and J.R. Ramos-Barrado, Solid State Ionics 180 (40) 1672 (2010)

86. O.A. Marina, L.R. Pederson, M.C. Williams, G.W. Coffey, K.D. Meinhardt, C.D. Nguyen and E.C. Thomsen, J. Electrochem. Soc. 154 (5) B452 (2007)

87. H. Falcón, J.A. Barbero, G. Araujo, M.T. Casais, M.J. Martínez-Lope, J.A. Alonso and J.L.G. Fierro, Applied Catalysis B: Environmental 53 (1) 37 (2004) 